\title{
Synthesis of 2-(arylthio)-3'-(alkyl- or dialkylamino)diphenyl sulfides via 5-arylthianthrenium perchlorates and their complexations with silver(I) and lead(II) ions
}

\author{
Kyongho Yoon, Kab Sig Kim, and Kyongtae Kim* \\ School of Chemistry and Molecular Engineering, Seoul National University, Seoul 151-742, \\ Korea \\ E-mail:kkim@plaza.snu.ac.kr
}

Dedicated to Professor Henry J. Shine on the occasion of his $80^{\text {th }}$ birthday

(received 18 Aug 03; accepted 12 Dec 03; published on the web 30 Dec 03)

\begin{abstract}
Treatment of 5-arylthianthrenium perchlorates 2 with secondary alkylamines in the presence of LDA in THF at reflux gave 2-(arylthio)-3'-(dialkylamino)diphenyl sulfides 7 as major products along with 2-(arylthio)-2'-(dialkylamino)diphenyl sulfides 8 and thianthrene. The latter two compounds were formed depending on the structures of amines employed and the concentrations of LDA. It has been found that the methoxy groups of $\mathbf{7 e}, \mathbf{7 g}$, and $\mathbf{7 h}$ were displaced by amide ions in the presence of excess amounts of LDA to give the corresponding 2-(4dialkylaminophenylthio)-3'-(dialkylamino)diphenyl sulfides (14a-c). The reactions with aza-15crown-5, aza-18-crown-6, and 7, 16-diaza-18-crown-6 gave analogous products via a benzyne intermediate.

The affinity of selected metal cations for compounds $7 \mathbf{a}, 7 \mathbf{e}-\mathbf{f}, \mathbf{7 h}, \mathbf{7 j}, \mathbf{7 m}, \mathbf{1 0}, \mathbf{1 3 a}$, and 18a was examined by an extraction method. The dialkylamino groups of $\mathbf{7 a}, \mathbf{7 e}, \mathbf{7 f}$, and $\mathbf{7 h}$ increased somewhat the extractive abilities of $\mathrm{Ag}^{+}$ion (14-28\%) compared with that of $\mathbf{1 0}(8 \%)$, whereas compound 13a having a diisopropylamino group showed low (9\%) and high (67\%) extractive abilities toward $\mathrm{Ag}^{+}$and $\mathrm{Pb}^{2+}$ ions, respectively. Compounds $\mathbf{7 j}$ and $\mathbf{7 m}$ having an aza-18-crown6 moiety showed $67 \%$ and $66 \%$ extractive abilities toward $\mathrm{Pb}^{2+}$ but $40 \%$ and $24 \%$ extractive abilities towards $\mathrm{Ag}^{+}$ions, respectively. However, compound 18a with two identical lariats showed high (86\%) and low (12\%) extractive abilities toward $\mathrm{Ag}^{+}$and $\mathrm{Pb}^{2+}$ ions, respectively.
\end{abstract}

Keywords: 2-(Arylthio)-3'-(dialkylamino)diphenyl sulfides, 2-(arylthio)-2'-(dialkylamino)diphenyl sulfides, 2-(4-dialkylaminophenylthio)-3'-(dialkylamino)diphenyl sulfides

\section{Introduction}


Thianthrene cation radical perchlorate (1) is a crystalline solid which is stable at room temperature under anhydrous conditions. Its physical and chemical properties and reactivity have been extensively studied. ${ }^{1}$ It reacts with aromatics having an electron-donating group in $\mathrm{CH}_{3} \mathrm{CN}$ at room temperature to give 5-arylthianthrenium perchlorates $2{ }^{2}$ It has been found that compounds 2 are useful precursors for the synthesis of some sulfur-containing organic compounds. For example, compound 2a was converted to 2-alkoxy-2'-(arylthio)diphenyl sulfides 3 on heating with alkoxide in alcohol at reflux. ${ }^{3}$ Dealkylation of 3 to give 2-(arylthio)-2'hydroxydiphenyl sulfides 4 (66 - 88\%) was achieved on heating with $48 \% \mathrm{HBr}$ in HOAc at $110^{\circ}$ $\mathrm{C}^{4}$ or stirring with $\mathrm{BBr}_{3}$ in $\mathrm{CH}_{2} \mathrm{Cl}_{2}$ at room temperature. ${ }^{5}$ Treatment of 2 with tert-BuOK in DMSO at room temperature gave 2-(arylsulfinyl)diphenyl sulfides $\mathbf{5}$, ${ }^{6}$ which are regioselective oxidation products of 2-(arylthio)diphenyl sulfides. Interestingly, heating a mixture of $\mathbf{2}$ and $\mathrm{NaSH} \cdot \mathrm{xH}_{2} \mathrm{O}$ in either $\mathrm{PhH} / \mathrm{H}_{2} \mathrm{O}(1: 1, \mathrm{v} / \mathrm{v})$ or $\mathrm{THF} / \mathrm{H}_{2} \mathrm{O}(10: 1, \mathrm{v} / \mathrm{v})$ at reflux resulted in the formation of 2,2'-bis[2-(arylthio)phenylthio]diphenyl sulfides $\mathbf{6}^{7}$

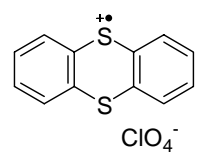

1

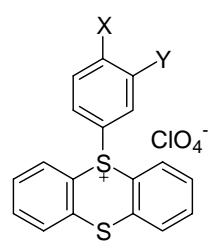

2

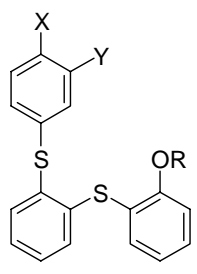

3

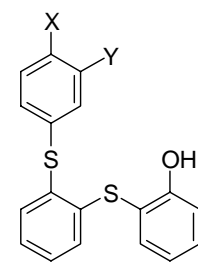

4

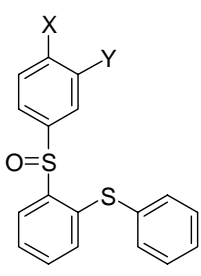

5

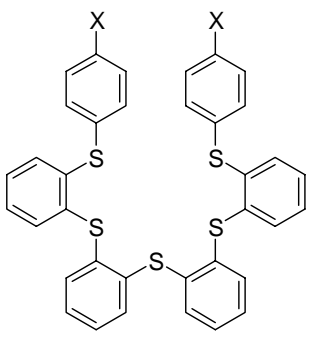

6

Recently, we reported that compounds $2(\mathrm{X}=\mathrm{MeO}, \mathrm{Y}=\mathrm{H})$ reacted with diethylamine in the presence of LDA in THF at reflux to give 2-(4-anisylthio)-3'-(diethylamino)diphenyl sulfide (7a) (57\%) and 2-(4-anisylthio)-2'-(diethylamino)diphenyl sulfide (8a) (11\%) together with thianthrene $(\mathbf{9})(8 \%)^{8}$ (Scheme 1).

Compound 7a was proven to be formed via a benzyne intermediate. This result suggests that compound 2 can be utilized as a new substituted benzyne precursor. To study the scope of the reaction, the reactions with diverse primary and secondary alkylamines were investigated. In addition, complexations of 7a, 7e $\left(X=\mathrm{MeO}, \mathrm{Y}=\mathrm{H}, \mathrm{R}=\mathrm{Pr}_{2} \mathrm{~N}\right)$, 7f $(\mathrm{X}=\mathrm{MeO}, \mathrm{Y}=\mathrm{H}, \mathrm{R}=$ $\left.\mathrm{Bu}_{2} \mathrm{~N}\right), 7 \mathbf{h}(\mathrm{X}=\mathrm{MeO}, \mathrm{Y}=\mathrm{H}, \mathrm{R}=-\xi \mathrm{N} J), \mathbf{j}(\mathrm{X}=\mathrm{MeO}, \mathrm{Y}=\mathrm{H}, \mathrm{R}=1,4,7,10,13$-pentaoxa-16azacyclooctadec-16-yl), 7m (X $=i$-PrO, $\mathrm{Y}=\mathrm{H}, \mathrm{R}=1,4,7,10,13$-pentaoxa-16-azacyclooctadec16-yl), 10 and 13a $\left(\mathrm{X}=\mathrm{MeO}, \mathrm{Y}=\mathrm{H}, \mathrm{R}=(i-\mathrm{Pr})_{2} \mathrm{~N}\right)$ with selected metal cations were studied in order to understand the effects of 2-(arylthio)phenylthio group as a lariat. The results are described herein. 


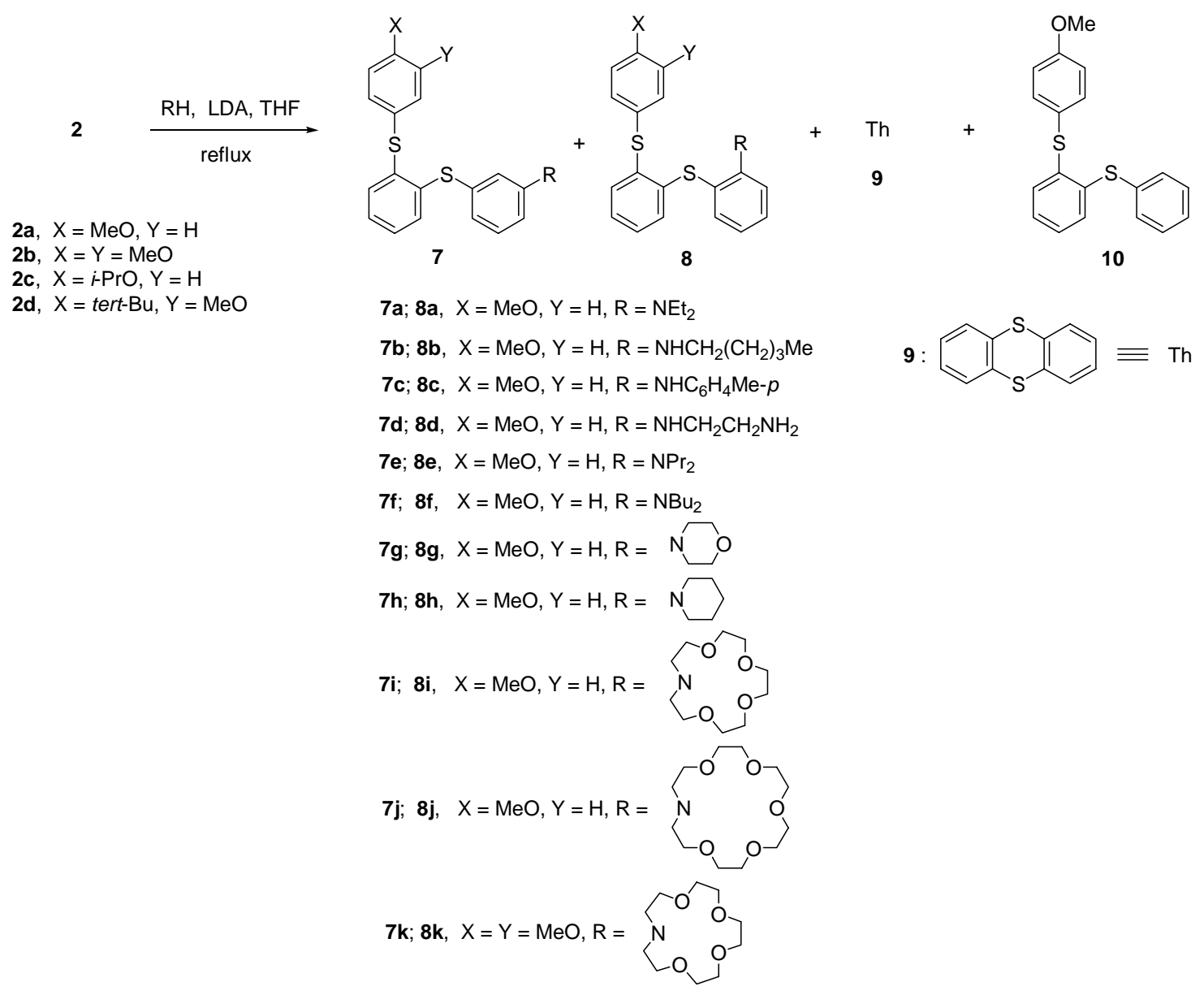

\section{Scheme 1}

\section{Results and Discussion}

To begin with, treatment of $\mathbf{2 a}$ with a primary alkylamine such as pentylamine (2.3 equiv.) in the presence of $\mathrm{NaH}$ (5.3 equiv.) for $3 \mathrm{~h}$ in THF at reflux gave 2-(4-methoxyphenylthio)-3'(pentylamino)diphenyl sulfide (7b) $(\mathrm{X}=\mathrm{MeO}, \mathrm{Y}=\mathrm{H}, \mathrm{R}=$ pentylNH) (21\%), 2-(4methoxyphenylthio)diphenyl sulfide (10) (31\%), and 9 (18\%) (entry 1, Table 1). No $8 \mathbf{b}(\mathrm{X}=$ $\mathrm{MeO}, \mathrm{Y}=\mathrm{H}, \mathrm{R}=$ pentylNH) was obtained. On the other hand, the same reaction was conducted by adding LDA ( $2 \mathrm{M}$, hexane) in place of $\mathrm{NaH}$. LDA $(0.3 \mathrm{~mL}, 0.6 \mathrm{mmol})$ was added six times at 40 min intervals during the reaction since LDA was expected to be deteriorated at reflux temperature. From the reaction were obtained $\mathbf{7 b}$ and $\mathbf{9}$ in 26 and $16 \%$ yields, respectively (entry 2, Table 1). No $\mathbf{8 b}$ was obtained. In order to identify the bonding position of the incoming $\mathrm{H}^{-}$ion leading to 10, 2a was treated with $\mathrm{NaD}$ in place of $\mathrm{NaH}$ under the same foregoing conditions to give deuterated 10 in 63\% yield (Scheme 2). However, the assignment of each of the aromatic protons of deuterated $\mathbf{1 0}$ on the basis of the ${ }^{1} \mathrm{H}$ NMR spectrum was unsuccessful simply because 
of poor resolution. Accordingly, the deuterated $\mathbf{1 0}$ was oxidized with $m$-CPBA to give disulfone 11.

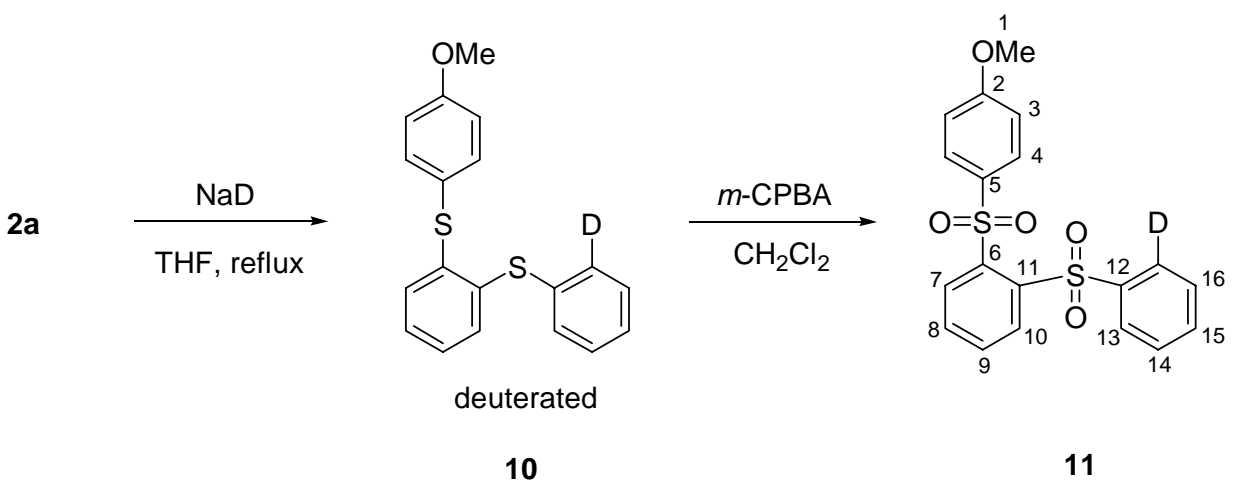

\section{Scheme 2}

The 2D NMR spectrum of 11 showed a multiplet at $7.94 \mathrm{ppm}$, assigned to two $\mathrm{H} 4$ protons and one H13 proton, whose intensity was compared with that obtained from the same compound not possessing a deuterium atom. Although we are aware of the deuterium atomic bonding position, further study is necessary to delineate the mechanism for the formation of 10. Similar reaction of 2 a with $p$-toluidine (2.0 equiv.) and $\mathrm{NaH}$ (2.3 equiv.) gave 7c $(\mathrm{X}=\mathrm{MeO}, \mathrm{Y}=\mathrm{H}, \mathrm{R}=$ $p$ - $\mathrm{MeC}_{6} \mathrm{H}_{4} \mathrm{NH}$ ) and 9 in 28 and 41\% yields, respectively (entry 3). No 10 was detected. Arylamine is more acidic than alkylamine which may account for decreased availability of $\mathrm{NaH}$. No 10 was detected in both reactions. Interestingly, the reaction of 2a with ethylenediamine (4 equiv.) and LDA (0.3 $\mathrm{mL} x$ 4) gave $7 \mathbf{d}\left(\mathrm{X}=\mathrm{MeO}, \mathrm{Y}=\mathrm{H}, \mathrm{R}=\mathrm{HNCH}_{2} \mathrm{CH}_{2} \mathrm{NH}_{2}\right)$ in $45 \%$ yield (entry 4), whereas $N, N$-disubstituted ethylenediamine derivative 12 was obtained in $72 \%$ yield when 2a (5 equiv.) was treated with ethylenediamine and LDA (0.3 mL x 8) (entry 5). Since a large quantity of 9 was obtained from the reaction with primary arylamine and $\mathrm{NaH}$ (entry 3 ), coupled with a relatively high yield of 7a from the reaction with diethylamine and LDA (entry 6 ), we decided to study the reactions of 2 with secondary alkylamines in the presence of LDA. The yields of 7, 8 , and $\mathbf{9}$ are summarized in Table 1.

Table 1. Quantities of 2 and amines, and yields of 7, 8, and 9

\begin{tabular}{|c|c|c|c|c|c|c|c|c|}
\hline \multirow{2}{*}{ entry } & \multirow{2}{*}{ compound } & \multirow{2}{*}{ mmol } & \multirow{2}{*}{$\mathrm{RH}^{b}$} & \multirow{2}{*}{ mmol } & \multirow{2}{*}{ compd } & \multicolumn{3}{|c|}{ yield $^{a}(\%)$} \\
\hline & & & & & & 7 & 8 & 9 \\
\hline 1 & $2 a$ & 0.71 & PentylNH${ }_{2}^{c}$ & 1.64 & b & 21 & 0 & 18 \\
\hline 2 & $2 a$ & 0.47 & PentylNH$_{2}$ & 4.02 & b & 26 & 0 & 16 \\
\hline 3 & $2 a$ & 0.47 & $\mathrm{MeC}_{6} \mathrm{H}_{4} \mathrm{NH}_{2}{ }^{c}$ & 0.95 & C & 28 & 0 & 41 \\
\hline 4 & $2 \mathbf{a}$ & 0.47 & $\mathrm{H}_{2} \mathrm{~N}\left(\mathrm{CH}_{2}\right)_{2} \mathrm{NH}_{2}{ }^{e}$ & 1.89 & d & 45 & 0 & 0 \\
\hline 5 & $2 \mathbf{a}$ & 2.32 & $\mathrm{H}_{2} \mathrm{~N}\left(\mathrm{CH}_{2}\right)_{2} \mathrm{NH}_{2}{ }^{g}$ & 0.46 & & & $m$ & \\
\hline 6 & $2 \mathbf{a}$ & 1.42 & $\mathrm{Et}_{2} \mathrm{NH}^{e, h}$ & 8.20 & $\mathbf{a}^{8}$ & 57 & 11 & 9 \\
\hline
\end{tabular}




\begin{tabular}{|c|c|c|c|c|c|c|c|c|}
\hline 7 & $2 \mathbf{a}$ & 0.47 & $\mathrm{Et}_{2} \mathrm{NH}^{d, e}$ & 6.84 & $\mathbf{a}$ & 51 & 19 & 18 \\
\hline 8 & $2 \mathbf{a}$ & 0.47 & $\mathrm{Pr}_{2} \mathrm{NH}^{g}$ & 1.89 & & & $n$ & \\
\hline 9 & $2 \mathbf{a}$ & 0.47 & $\mathrm{Pr}_{2} \mathrm{NH}^{d, e}$ & excess & $\mathbf{e}$ & 55 & 0 & 0 \\
\hline 10 & $2 \mathbf{a}$ & 0.54 & $\mathrm{Bu}_{2} \mathrm{NH}^{e}$ & excess & f & 29 & 2 & 25 \\
\hline 11 & $2 a$ & 0.47 & & 1.18 & g & 74 & 15 & 0 \\
\hline 12 & $2 \mathbf{a}$ & 0.47 & & 1.18 & & & $o$ & \\
\hline 13 & $2 \mathbf{a}$ & 0.47 & & 3.52 & $\mathbf{h}$ & 62 & 14 & 9 \\
\hline 14 & $2 \mathbf{a}$ & 0.47 & & excess & & & $p$ & \\
\hline 15 & $2 \mathbf{a}$ & 2.32 & & 0.46 & & & $q$ & \\
\hline 16 & $2 \mathbf{a}$ & 1.68 & 1-aza-15-crown-5 $5^{f, h}$ & 0.56 & $\mathbf{i}$ & 33 & 0 & $\mathrm{sm}^{t}$ \\
\hline 17 & $2 \mathbf{a}$ & 1.20 & 1-aza-18-crown-6 ${ }^{f, h}$ & 0.40 & $\mathbf{j}$ & 82 & 0 & $\mathrm{sm}$ \\
\hline 18 & $2 \mathbf{a}$ & 2.29 & $\begin{array}{l}\text { 1,4,10,13-tetraoxa- } \\
\text { 7,16-diazacyclo- } \\
\text { octadecane }^{f, h}\end{array}$ & 0.38 & & & $r$ & \\
\hline 19 & $2 \mathbf{b}$ & 1.17 & 1-aza-15-crown-5 $5^{f, j}$ & 0.57 & $\mathbf{k}$ & 40 & & \\
\hline 20 & $2 \mathbf{b}$ & 2.22 & 1-aza-18-crown- $6^{f, j}$ & 0.44 & 1 & 56 & 0 & $\mathrm{sm}$ \\
\hline 21 & $2 \mathbf{b}$ & 3.32 & $\begin{array}{l}\text { 1,4,10,13-tetraoxa- } \\
\text { 7,16-diazacyclo- } \\
\text { octadecane }^{f, j}\end{array}$ & 0.42 & & & $s$ & \\
\hline 22 & 2c & 2.44 & 1-aza-18-crown- $6^{f, k}$ & 0.41 & m & 47 & 0 & $\mathrm{sm}$ \\
\hline 23 & $2 d$ & 1.96 & 1-aza-18-crown-6 $f, l$ & 0.39 & $\mathbf{n}$ & 41 & 0 & $\mathrm{sm}$ \\
\hline
\end{tabular}

${ }^{a}$ Isolated yields. ${ }^{b}$ For the reactions (entries $1-4$ and 6 - 14), excess molar amounts of amines were used compared with those of 2 . For the remainder (entries 5 and $15-23$ ), yields of products were calculated based on the amounts of amines employed. ${ }^{c}$ LDA ( $2 \mathrm{M}$, hexane) was used as a base except for two cases (entries 1 and 3) where $\mathrm{NaH}$ was employed. Each time $0.3 \mathrm{~mL}$ of LDA was added at $40 \mathrm{~min}$ intervals during the reaction. The number of additions is specified each case. ${ }^{d}$ Dried amines were used. Otherwise, purchased amines were used. ${ }^{e}$ Number of additions of LDA: $2 .{ }^{f}$ Number of additions of LDA: $6 .{ }^{g}$ Number of additions of LDA: $8 .{ }^{h}$ Additionally a spot corresponding to 13a was observed on TLC (silica-gel, EtOAc/hexane $=1: 3$ ). ${ }^{i}$

Additionally 13a was obtained in $27 \%$ yield. ${ }^{j}$ A spot corresponding to $\mathbf{1 3 b}$ was observed on TLC. ${ }^{k}$ A spot corresponding to $13 \mathrm{c}$ was observed on TLC. ${ }^{l}$ A spot corresponding to 13d was observed on TLC. ${ }^{m}$ Compounds 12 and $\mathbf{9}$ were obtained in 72 and $11 \%$ yields, respectively. ${ }^{n}$ Compounds 14a, 15a, and 9 were obtained in 49,10 , and $15 \%$ yields, respectively. ${ }^{\circ}$ Compounds 14b and 15b were obtained in 42 and $17 \%$ yields, respectively. ${ }^{p}$ Compounds 14c was obtained in $45 \%$ yield. ${ }^{q}$ Compound $\mathbf{1 7}$ was obtained in $71 \%$ yield. ${ }^{r}$ Compounds $\mathbf{1 8 a}$ was obtained in $55 \%$ yield. ${ }^{s}$ Compound $\mathbf{1 8 b}$ was obtained in $33 \%$ yield. ${ }^{t} \mathrm{sm}$ : small amount. In the cases of entries 15 - 23, a mixtures of small amounts of $\mathbf{9}$ and unidentifiable materials were obtained. 


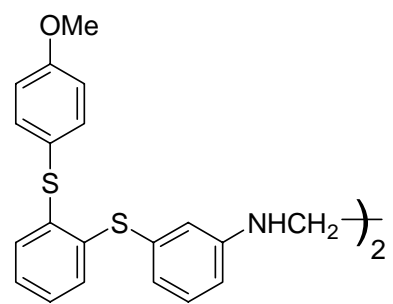

12

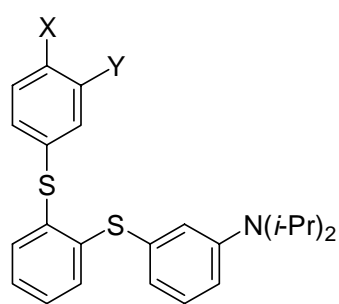

13a, $X=\mathrm{MeO}, \mathrm{Y}=\mathrm{H}$ 13b, $X=Y=\mathrm{MeO}$ 13c, $X=i-P r O, Y=H$ 13d, $X=$ tert-Bu, $Y=\mathrm{MeO}$

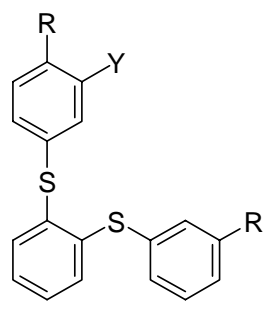

14

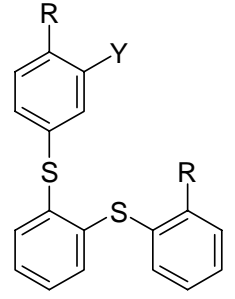

15

a, $\mathrm{R}=\mathrm{NPr}_{2}, \mathrm{Y}=\mathrm{H}$

b, $\mathrm{R}=\mathrm{N} \mathrm{O}, \mathrm{Y}=\mathrm{H}$

c. $\mathrm{R}=\mathrm{N}, \mathrm{Y}=\mathrm{H}$

The structures of compounds 7a-n, 8a, 8f-h, 13a, 14a-c, 15a-b, 17, 18a-b were identified on the basis of spectroscopic $\left({ }^{1} \mathrm{H}\right.$ and ${ }^{13} \mathrm{C}$ NMR, IR, MS) and analytical data. Reactions with dried amines (i.e., diethylamine (entry 7) and dipropylamine (entry 9)) were compared with reactions where the same amines had not been previously dried. When purchased $\mathrm{Et}_{2} \mathrm{NH}$ (5.7 equiv.) and LDA (0.3 mL x 2) were employed, 7a, 8a, and 9 were obtained (entry 6). In addition, a spot corresponding to 13a was observed on TLC (EtOAc : hexane $\left.=1: 3, \mathrm{R}_{\mathrm{f}}=0.45\right)$. By employing a dried excess amount of $\mathrm{Et}_{2} \mathrm{NH}$ (15 equiv.) and the same amount of LDA, only 7a, 8a, and 9 were obtained in 51, 19, and 18\% yields, respectively (entry 7). Yields of 7a, 8a, and $\mathbf{9}$ seemed to be independent of the dryness of $\mathrm{Et}_{2} \mathrm{NH}$. In addition, no spot corresponding to 13a was observed from the latter reaction presumably due to the low concentrations of diisopropylamide ion in the presence of excess $\mathrm{Et}_{2} \mathrm{NH}$.

For the reactions with an excess amount of dried $\operatorname{Pr}_{2} \mathrm{NH}$ and LDA (0.3 mL x 2) (entry 9), 7e was obtained in 55\% yield, whereas the reaction with purchased $\operatorname{Pr}_{2} \mathrm{NH}$ (4 equiv.) and LDA $(0.3$ $\mathrm{mL}$ x 8 ) gave 14a, 15a, and 9 in 49, 10, and 15\% yields (entry 8 ) instead of 7e and 8e. This result indicates that the reactions depend strongly on the concentration of LDA rather than the dryness of purchased amines. The formation of 14a and 15a may be achieved via a nucleophilic displacement of the methoxy groups of $\mathbf{7 e}$ and $\mathbf{8 e}$ by dipropylamide ion. The displacement of the methoxy group in preference to the phenylthio group indicates that the first step corresponding to a nucleophilic attack of an amide ion is a rate determining step. ${ }^{9}$ However, the electronic (for 7e and $\mathbf{8 e}$ ) and steric (for $\mathbf{8 e}$ ) effects of dipropyl groups of $7 \mathbf{e}$ and $\mathbf{8 e}$ cannot be ruled out.

The importance of the concentrations of LDA was also observed from the reaction with dried morpholine (entries 11 and 12) and dried piperidine (entries 13 and 14). That is, $0.3 \mathrm{~mL}$ of LDA was added twice (entry 11) and eight times (entry 12) to the same amounts of a mixture of 2a and morpholine, respectively. After the reaction mixture was allowed to proceed for $6 \mathrm{~h}$, the former reaction gave $\mathbf{7 g}$ and $\mathbf{8 g}$ in 74 and $15 \%$ yields, respectively, whereas the latter reaction gave 14b and 15b in 42 and 17\% yields, respectively. The structure of $\mathbf{1 4 b}$ was confirmed by Xray crystallography (Figure 1). 


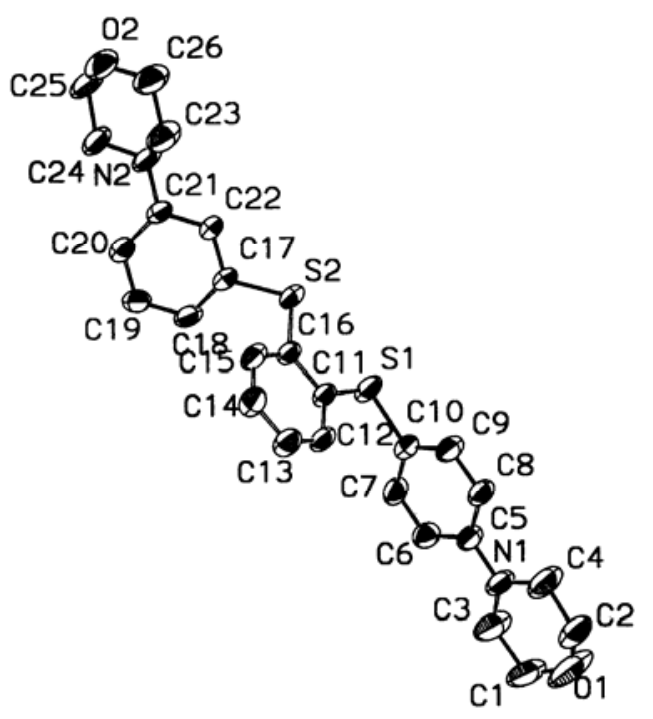

Figure 1. ORTEP drawing of $\mathbf{1 4 b .}$

The formation of $\mathbf{1 4 b}$ from $\mathbf{7 g}$ was confirmed by an independent study in which treatment of $7 \mathrm{~g}$ (144 mg, $0.35 \mathrm{mmol})$ with dried morpholine $(150 \mathrm{mg}, 1.72 \mathrm{mmol})$ and LDA (0.3 $\mathrm{mL} \times \mathrm{6})$ under the same foregoing conditions gave 14b in $92 \%$ yield. However, the same reaction of $\mathbf{7 g}$ with $\mathrm{Et}_{2} \mathrm{NH}$ did not give the corresponding substitution product 16. The failure to form $\mathbf{1 6}$ may be due to the low boiling point of $\mathrm{Et}_{2} \mathrm{NH}$. Similarly, the reaction with piperidine ( 7.5 equiv.) and LDA (0.3 mL x 2) gave $7 \mathbf{h}, \mathbf{8 h}$, and $\mathbf{9}$ in 62,14 , and $9 \%$ yields, respectively (entry 13), whereas the reaction with an excess amount of piperidine and LDA $(0.3 \mathrm{~mL} \times 8)$ resulted in the formation of $\mathbf{1 4 c}$ in $45 \%$. No $\mathbf{7 h}$ and $\mathbf{8 h}$ were obtained.

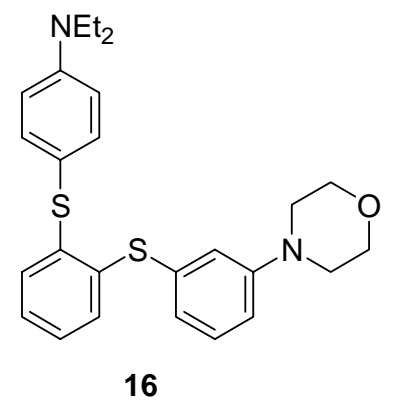

The reaction with piperazine (0.2 molar equiv.) and LDA $(0.3 \mathrm{~mL}$ x 6$)$ gave $N, N$ '-bis[3- $\{2-(4-$ methoxyphenylthio)phenylthio\}phenyl]piperazine (17) and 13a in 71 and $27 \%$ yields, respectively, along with a small amount of 9 containing some unidentifiable mixtures (entry 15). 


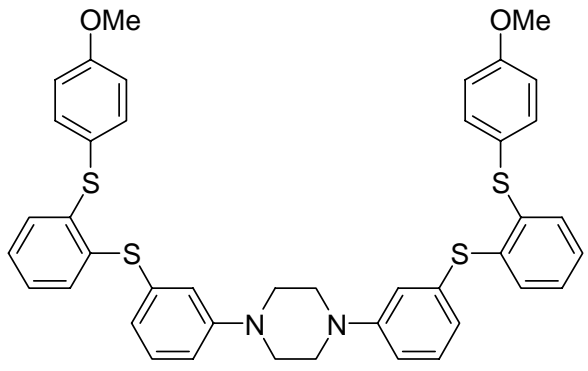

17

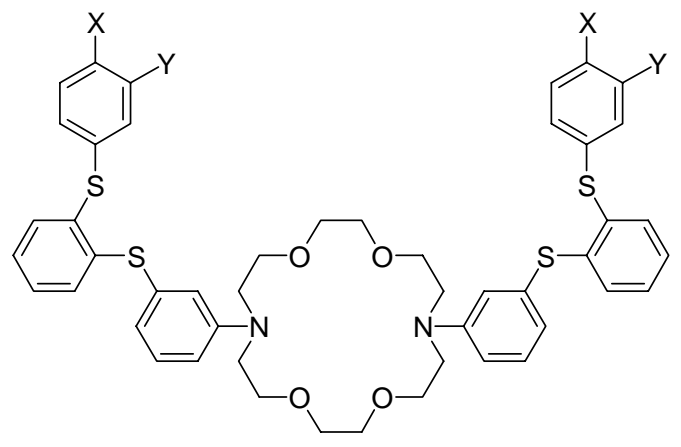

18a, $X=\mathrm{MeO}, \mathrm{Y}=\mathrm{H}$

18b, $X=Y=\mathrm{MeO}$

The reactions of azacrown ethers, i.e., aza-15-crown-5 (1,4,7,10-tetraoxa-13azacyclopentadecane) and aza-18-crown-6 (1,4,7,10,13-pentaoxa-16-azacyclooctadecane), with 2a (3 equiv.) (entries 16 - 17) and LDA $(0.3 \mathrm{~mL}$ x 6$)$ gave the corresponding $N$-[3-\{2-(4methoxyphenylthio)phenylthio phenyl]-1-azacrown ethers (7i-j) together with a small amount of 13a and 9. In the meantime, the same reaction of 7,16-diaza-18-crown-6 (1,4,10,13-tetraoxa7,16-diazacyclooctadecane) with 2a (6 equiv.) under the same conditions gave 18a in 55\% yield (entry 18). Similar reactions of $\mathbf{2 b}(\mathrm{X}=\mathrm{Y}=\mathrm{MeO})$ (entries 19 - 20), 2c $(\mathrm{X}=i$-PrO, $\mathrm{Y}=\mathrm{H})$ (entry $22)$, and $2 \mathbf{d}(\mathrm{X}=$ tert $-\mathrm{Bu}, \mathrm{Y}=\mathrm{MeO})$ (entry 23$)$ in the presence of LDA $(0.3 \mathrm{~mL} \times 6)$ under the same foregoing conditions gave the corresponding $7 \mathbf{k}-\mathbf{l}$ and $\mathbf{7 m - n}$ together with $\mathbf{1 3 b}(\mathrm{X}=\mathrm{Y}=$ $\mathrm{MeO})$, 13c $(\mathrm{X}=i$-PrO, $\mathrm{Y}=\mathrm{H})$, and 13d $(\mathrm{X}=$ tert- $\mathrm{Bu}, \mathrm{Y}=\mathrm{MeO})$, respectively, and a small amount of $\mathbf{9}$. Treatment of 7,16-diaza-18-crown- 6 with $\mathbf{2 b}$ (7.9 equiv.) under the same conditions gave $\mathbf{1 8 b}$ in $33 \%$ yield (entry 21 ).

Complexations of some prepared sulfur-containing compounds.

(a) Extractive ability

The affinity of selected metal cations to compounds $7 \mathbf{a}, 7 \mathbf{e}-\mathbf{f}, 7 \mathbf{h}, 7 \mathbf{j}, 7 \mathbf{m}, \mathbf{1 0}, \mathbf{1 3 a}$, and $\mathbf{1 8 a}$ was examined by mixing a deionized aqueous solution of a metal picrate $\left(5 \times 10^{-3} \mathrm{M}, 2 \mathrm{~mL}\right)$, prepared by a reported procedure, ${ }^{10}$ with each of the host compounds in $\mathrm{CHCl}_{3}\left(1 \times 10^{-3} \mathrm{M}, 2\right.$ $\mathrm{mL}$ ). The mixture was vigorously stirred, followed by maintenance at constant temperature for $12 \mathrm{~h}$. The extractive ability defined in equation 1 was calculated, where the subtraction of the picrate transferred into the plain $\mathrm{CHCl}_{3}$ from the initial concentration of picrate in the aqueous phase is the $\left[\mathrm{M}_{\mathrm{aq}}\right]$ value, and $\left[\mathrm{M}_{\mathrm{t}}\right]$ is the concentration of picrate in the aqueous phase after extraction. $\left[\mathrm{H}_{\mathrm{o}}\right]$ is the concentration of the host molecule. The results are tabulated in Table 2 .

Extractive ability $(\%)=\left(\left(\left[\mathrm{M}_{\mathrm{aq}}\right]-\left[\mathrm{M}_{\mathrm{t}}\right]\right) /\left[\mathrm{H}_{\mathrm{o}}\right]\right) \times 100$

Table 2. Extractive ability of some compounds

\begin{tabular}{|c|c|c|c|c|c|c|c|c|c|}
\hline metal ion & 10 & $7 a$ & $7 e$ & $7 f$ & $7 \mathrm{~h}$ & $7 \mathbf{j}$ & $7 m$ & 18a & 13a \\
\hline
\end{tabular}




\begin{tabular}{c|ccccccccc}
\hline $\mathrm{Na}^{+}$ & 0 & 3 & 0 & 0 & 6 & 0 & 0 & 0 & 3 \\
$\mathrm{~K}^{+}$ & 4 & 1 & 0 & 0 & 4 & 0 & 0 & 0 & 5 \\
$\mathrm{Cs}^{+}$ & 8 & 3 & 0 & 0 & 8 & 0 & 0 & 0 & 0 \\
$\mathrm{Cu}^{2+}$ & 0 & 9 & 4 & 7 & 10 & 0 & 0 & 3 & 24 \\
$\mathrm{Ag}^{+}$ & 8 & 28 & 18 & 14 & 28 & 40 & 24 & 86 & 9 \\
$\mathrm{Cd}^{2+}$ & 0 & 4 & 6 & 1 & 3 & 0 & 0 & 1 & 10 \\
$\mathrm{Ba}^{2+}$ & 3 & 1 & 0 & 0 & 3 & 19 & 15 & 0 & 0 \\
$\mathrm{~Pb}^{2+}$ & 0 & 18 & 5 & 7 & 19 & 67 & 66 & 12 & 67 \\
\hline
\end{tabular}

Table 2 shows that the extractive abilities of $\mathbf{1 0}$ toward all metal cations employed are essentially zero. In contrast, the extractive abilities of 7a having a diethylamino group at the meta position toward $\mathrm{Ag}^{+}$and $\mathrm{Pb}^{2+}$ ions increased somewhat to 28 and $18 \%$, respectively. On the other hand, the extractive abilities of 7e and 7f having a dipropyl- and dibutylamino group, respectively, in place of a diethylamino group of 7a toward the same metal ions decreased to 18 and $5 \%$, respectively, for $7 \mathbf{e}$, and to 14 and $7 \%$, respectively, for $7 \mathbf{f}$. The results suggest that the nonbonding electrons on the amino group at the meta position are somehow involved in the complexations with both $\mathrm{Ag}^{+}$and $\mathrm{Pb}^{2+}$ ions. However, bulky groups such as the dipropyl- and dibutylamino groups are envisaged to reduce the efficiency of the complexations, presumably due to the steric hindrance. Compound $\mathbf{7 h}$, having a piperidine moiety at the same meta position showed almost the same extractive abilities as those of 7 a toward $\mathrm{Ag}^{+}$and $\mathrm{Pb}^{2+}$ ions. This may be ascribed to the similar electronic and steric effects of the piperidine ring and diethylamino group. In this regard, it is necessary to explain the observation in which compound 13a, having a diisopropylamino group at the same meta position, showed a very low extractive ability (9\%) toward $\mathrm{Ag}^{+}$ion and a relatively high extractive ability (67\%) toward $\mathrm{Pb}^{2+}$ ion. One might explain the different tendencies in the extractive ability of 13a toward $\mathrm{Ag}^{+}$ion and $\mathrm{Pb}^{2+}$ ions by presuming the involvement of two molecules of 13a in producing a cavity for complexing metal ions. The cavity may be suitable for accommodation of the smaller $\mathrm{Pb}^{2+}$ ions (ionic radius $=1.20$ $\AA$ ) compared with $\mathrm{Ag}^{+}$ions (ionic radius $=1.26 \AA$ ). ${ }^{11}$

Figure 2 shows molecular mechanics-calculated conformations (MN2 ${ }^{+}$force field, MC/SD conformational search) ${ }^{12}$ of (a) 13a (parallel) $-\mathrm{Pb}^{2+}$, (b) 13a (parallel, T-shaped ${ }^{13}$ ) - $\mathrm{Pb}^{2+}$, and (c) 13a (anti-parallel) $-\mathrm{Pb}^{2+}$ picrate complexes. 


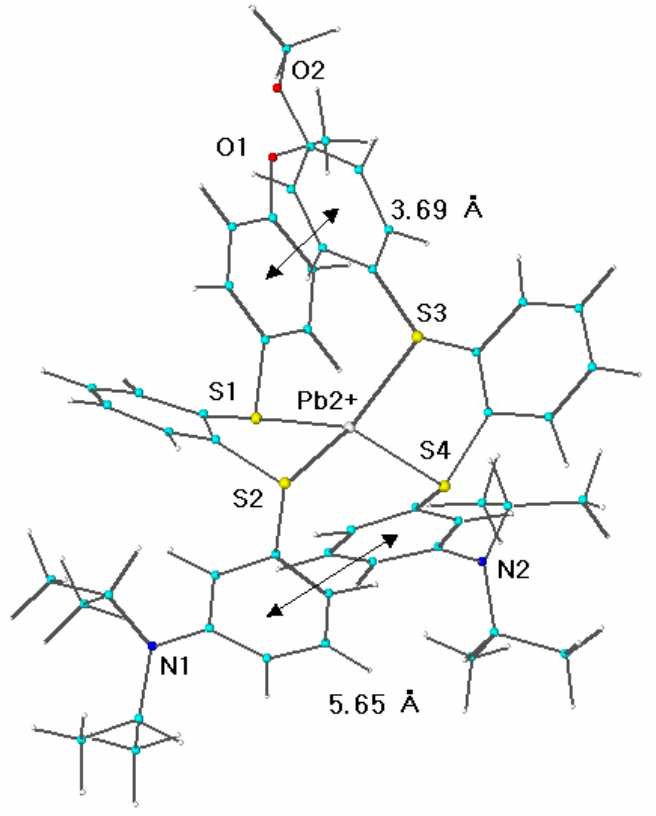

(a)

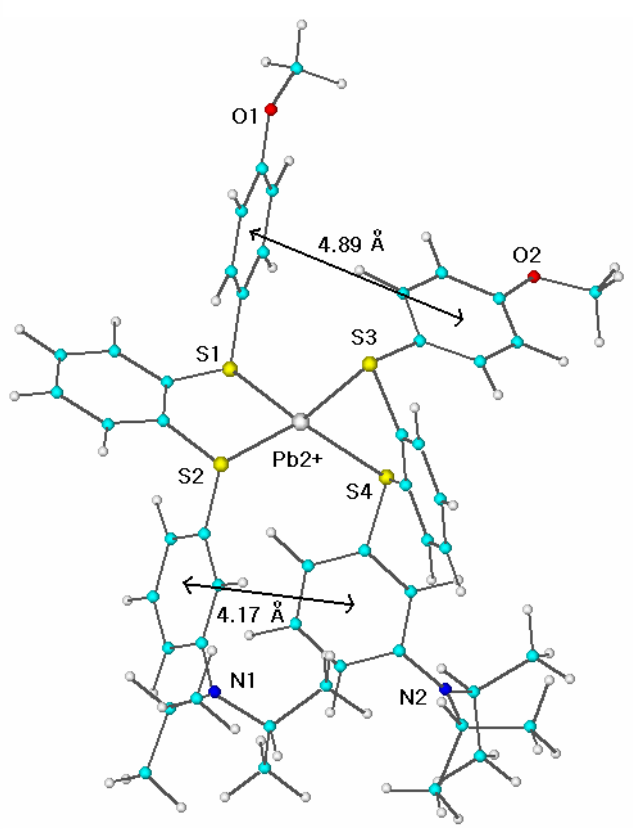

(b)

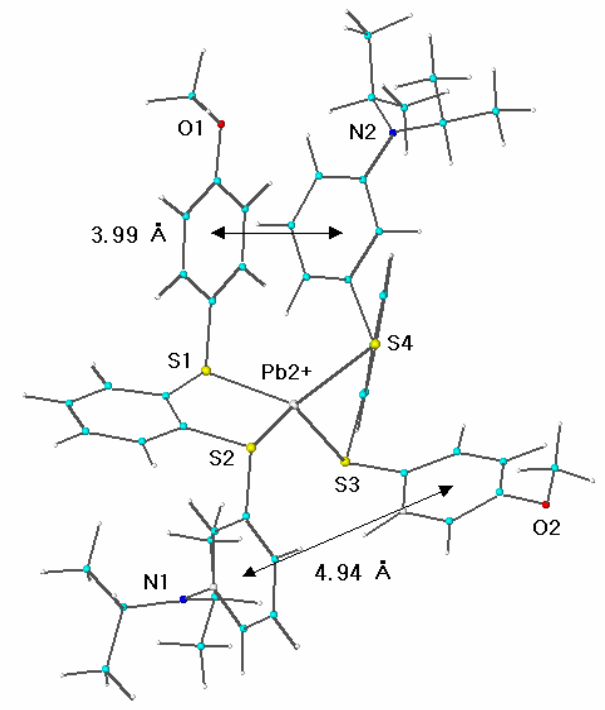

(c)

Figure 2. Molecular mechanics-calculated conformations of (a) 13a (parallel) $-\mathrm{Pb}^{2+}$, (b) 13a (parallel, $\mathrm{T}$-shaped) $-\mathrm{Pb}^{2+}$, and (c) 13a (anti-parallel) - $\mathrm{Pb}^{2+}$ picrate complexes.

The non-bonded distances between the middle of the methoxyphenyl groups bonded to S1 and S3 atoms, and two diisopropylaminophenyl groups bonded to S2 and S4 atoms of the 13a (parallel) $-\mathrm{Pb}^{2+}$ and the 13a (parallel, $\mathrm{T}$-shaped) $-\mathrm{Pb}^{2+}$ picrate complexes are calculated to be 3.69 and $5.65 \AA$, and 4.89 and $4.17 \AA$, respectively. Similarly, the non-bonded distances between two phenyl groups bonded to $\mathrm{S} 1$ and $\mathrm{S} 4$, and $\mathrm{S} 2$ and $\mathrm{S} 3$ atoms of the 13a (anti-parallel) $-\mathrm{Pb}^{2+}$ are 
3.99 and $4.94 \AA$, respectively. The distances over $4 \AA$ are a little greater for $\pi$ - $\pi$ stacking interactions. ${ }^{14}$ It shows that a $\mathrm{Pb}^{2+}$ ion interacts with four sulfur atoms whose geometry resembles a crushed tetrahedral (refer to the supporting information (SI) for non-bonded distance and bond angle). The interaction energies between the HOMO of 13a and the LUMO of $\mathrm{Pb}^{2+}$ ion (refer to the SI for the energies of the HOMO and the LUMO), ${ }^{15}$ and the thermodynamic energies of the complexes are summarized in Table 3.

Table 3. The energy differences between the HOMO of 13a and the LUMO of metal cations $\left(\mathrm{Pb}^{2+}, \mathrm{Ag}^{+}\right)$and the thermodynamic energies of $\mathbf{1 3 a}-$ metal cation complexes at $25^{\circ} \mathrm{C}$

\begin{tabular}{|c|c|c|c|c|c|}
\hline energy & $\begin{array}{l}\text { 13a }(\mathrm{P})- \\
\mathrm{Pb}^{2+}\end{array}$ & $\begin{array}{c}\text { 13a }(\mathrm{P}, \mathrm{T})- \\
\mathrm{Pb}^{2+}\end{array}$ & $\begin{array}{c}\text { 13a (A P) - } \\
\mathrm{Pb}^{2+}\end{array}$ & 13a $(\mathrm{P})-\mathrm{Ag}^{+}$ & $\begin{array}{c}\text { 13a (A P) - } \\
\mathrm{Ag}^{+}\end{array}$ \\
\hline $\begin{array}{c}\Delta \mathrm{E}(\mathrm{HOMO}-\mathrm{LUMO}) \\
\mathrm{eV}\end{array}$ & $\begin{array}{c}9.332 \\
(\alpha \& \beta)\end{array}$ & $\begin{array}{l}1.903(\alpha) \\
1.879(\beta)\end{array}$ & $\begin{array}{c}8.687 \\
(\alpha \& \beta)\end{array}$ & $\begin{array}{l}12.272(\alpha) \\
12.979(\beta)\end{array}$ & $\begin{array}{l}11.024(\alpha) \\
11.669(\beta)\end{array}$ \\
\hline $\begin{array}{c}\text { E (thermodynamic) } \\
\mathrm{kcal} / \mathrm{mol}\end{array}$ & $1,053.17$ & 42.18 & $1,071.23$ & $1,269.92$ & $1,284.25$ \\
\hline
\end{tabular}

P: parallel; A P: anti-parallel; T: T-shaped; $\alpha: \alpha$-spin; $\beta$ : $\beta$-spin.

The data show that the 13a (parallel, T-shaped) $-\mathrm{Pb}^{2+}$ picrate complex has a lower thermodynamic energy compared with other complexes by 1011 to $1029 \mathrm{kcal} / \mathrm{mol}$. Furthermore, the smallest HOMO -LUMO interaction energy $(1.9 \mathrm{eV})$ is involved in the formation of the complex. Consequently, not only the thermodynamic stability of the complex but also the HOMO - LUMO interaction energy are envisaged to play an important role leading to the formation of the 13a (parallel, $\mathrm{T}$-shaped) - $\mathrm{Pb}^{2+}$ picrate complex.

Figure 3 shows conformations of (a) 13a (parallel) $-\mathrm{Ag}^{+}$and (b) 13a (anti-parallel) $-\mathrm{Ag}^{+}$ picrate complexes obtained by the same method as for $13 \mathbf{a}-\mathrm{Pb}^{2+}$ picrate complex. 


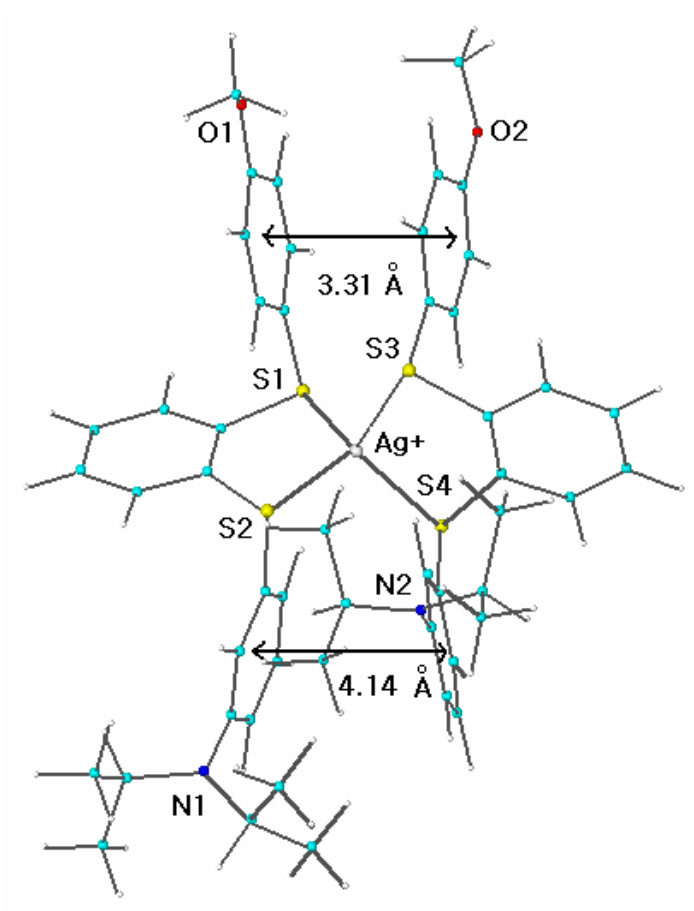

(a)

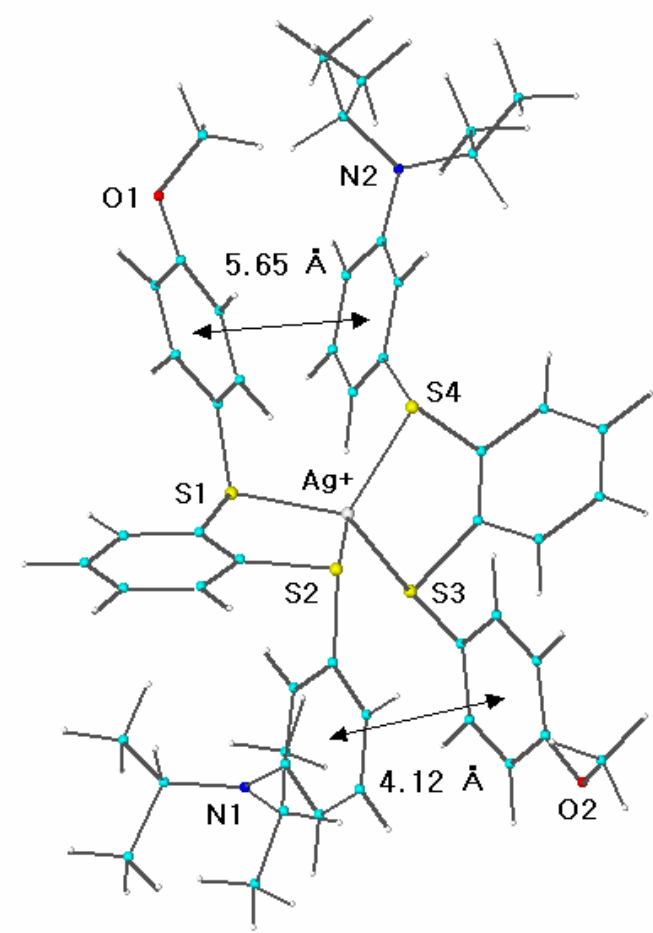

(b)

Figure 3. Molecular mechanics-calculated conformations of (a) 13a (parallel) $-\mathrm{Ag}^{+}$and (b) 13a (anti-parallel) $-\mathrm{Ag}^{+}$picrate complexes.

The 13a (parallel) $-\mathrm{Ag}^{+}$picrate complex shows that the $\mathrm{Ag}^{+}$ion forms a kind of tetrahedral geometry with four sulfur atoms. The non-bonded distances between two methoxyphenyl groups bonded to S1 and S3 atoms, and those of the two diisopropylaminophenyl groups bonded to S2 and S4 atoms of the 13a (parallel) $-\mathrm{Ag}^{+}$picrate complex, obtained by the same method as for the 13a $-\mathrm{Pb}^{2+}$ picrate complexes, are 3.31 and $4.14 \AA$, respectively. A $\pi$ - $\pi$ stacking interaction may be possible only between two methoxyphenyl groups. The HOMO - LUMO interaction energies between 13a and $\mathrm{Ag}^{+}$ion and the thermodynamic energies of the 13a (parallel) $-\mathrm{Ag}^{+}$ and the 13a (anti-parallel) $-\mathrm{Ag}^{+}$picrate complexes are summarized in Table 3 . The data show that the latter has a smaller HOMO - LUMO interaction energy compared with that of the latter by $1.25 \mathrm{eV}$ for $\alpha$-spin and $1.31 \mathrm{eV}$ for $\beta$-spin but it is less stable than the former by 14.33 $\mathrm{kcal} / \mathrm{mol}$. Accordingly, it may be difficult to predict a plausible conformation for the complex formed by 13a and $\mathrm{Ag}^{+}$picrate based on the thermodynamic energy and the HOMO - LUMO interaction energy. Nevertheless, it may be envisaged that the lower thermodynamic energy as well as a smaller HOMO - LUMO interaction energy of the 13a (parallel, T-shaped) $-\mathrm{Pb}^{2+}$ picrate complex compared with corresponding value for the $13 \mathbf{a}-\mathrm{Ag}^{+}$picrate complex may be responsible for a higher extractive ability of 13a toward $\mathrm{Pb}^{2+}$ ion compared with $\mathrm{Ag}^{+}$ion.

Figure 4 shows conformation of (a) 7a (parallel) $-\mathrm{Ag}^{+}$and (b) 7a (anti-parallel) $-\mathrm{Ag}^{+}$ picrate complexes obtained by the same method as for $\mathbf{1 3 a}-\mathrm{Ag}^{+}$picrate complex. The non- 
bonded distances between two methoxyphenylgroups bonded to S1 and S3 atoms and two diethylaminophenyl groups bonded to S2 and S4 atoms

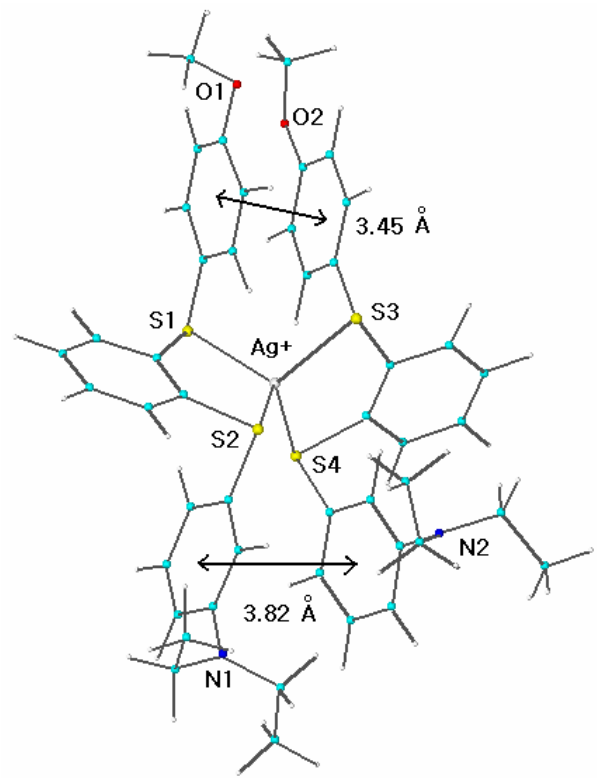

(a)

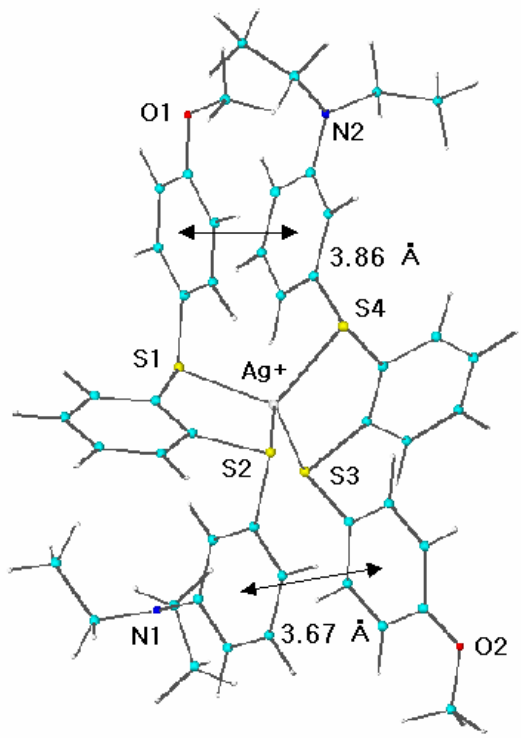

(b)

Figure 4. Molecular mechanics-calculated conformations of (a) 7a (parallel) $-\mathrm{Ag}^{+}$and (b) 7a (anti-parallel) $-\mathrm{Ag}^{+}$picrate complexes.

of the 7a (parallel) $-\mathrm{Ag}^{+}$picrate complex, determined by the same method as before, are 3.45 and $3.82 \AA$, respectively, which suggests possible $\pi$ - $\pi$ stacking interactions between two pairs of the phenyl rings. Similar calculations conducted on the 7a (anti-parallel) $-\mathrm{Ag}^{+}$picrate complex show that the non-bonded distances between methoxyphenyl group bonded to S1 and diethylaminophenyl group bonded to $\mathrm{S} 4$, and diethylaminophenyl group bonded to S2 and methoxyphenyl group bonded to S3 atoms are 3.86 and $3.67 \AA$, respectively. The non-bonded distances between the phenyl groups of the 7a (anti-parallel) $-\mathrm{Ag}^{+}$picrate complex are reasonable distances for $\pi-\pi$ stacking interactions as is the case for the 7a (parallel) $-\mathrm{Ag}^{+}$picrate complex. In the meantime, the calculated HOMO - LUMO interaction energies between 7a and $\mathrm{Ag}^{+}$picrate and the thermodynamic energies of the $\mathbf{7 a}-\mathrm{Ag}^{+}$picrate complex are summarized in Table 4 (7a (parallel, T-stacking) $-\mathrm{Ag}^{+}$picrate complex is improbable).

Table 4. The energy differences between the HOMO of 7a and the LUMO of metal cations $\left(\mathrm{Pb}^{2+}\right.$, $\mathrm{Ag}^{+}$) and the thermodynamic energies of $7 \mathbf{a}$ - metal cation complexes at $25{ }^{\circ} \mathrm{C}$

\begin{tabular}{|c|c|c|c|c|}
\hline energy & $7 \mathbf{a}(\mathrm{P})-\mathrm{Ag}^{+}$ & 7a $(\mathrm{A} \mathrm{P})-\mathrm{Ag}^{+}$ & $7 \mathbf{a}(\mathrm{P})-\mathrm{Pb}^{2+}$ & $7 \mathbf{a}(\mathrm{A} P)-\mathrm{Pb}^{2+}$ \\
\hline
\end{tabular}




\begin{tabular}{c|cc|cc}
\hline $\begin{array}{c}\Delta \mathrm{E}(\mathrm{HOMO}-\mathrm{LUMO}) \\
\mathrm{eV}\end{array}$ & $\begin{array}{c}10.879(\alpha) \\
10.008(\beta)\end{array}$ & $\begin{array}{c}12.324(\alpha) \\
10.687(\beta)\end{array}$ & $\begin{array}{c}12.352 \\
(\alpha \& \beta)\end{array}$ & $\begin{array}{c}9.461(\alpha) \\
\text { \& } \beta .191(\beta)\end{array}$ \\
\hline $\begin{array}{c}\mathrm{E}(\text { thermodynamic) } \\
\mathrm{kcal} / \mathrm{mol}\end{array}$ & $1,004.15$ & $1,273.87$ & $1,307.18$ & $1,087.17$ \\
\hline
\end{tabular}

The data show that the 7a (parallel) $-\mathrm{Ag}^{+}$picrate complex has a smaller HOMO - LUMO interaction energy than the 7a (anti-parallel) $-\mathrm{Ag}^{+}$picrate complex by $1.4 \mathrm{eV}$ for $\alpha$-spin and $0.68 \mathrm{eV}$ for $\beta$-spin. In addition, the former has a lower thermodynamic energy than the latter by $270 \mathrm{kcal} / \mathrm{mol}$. Accordingly, it is conceivable that the formation of 7a (parallel) $-\mathrm{Ag}^{+} \mathrm{picrate}$ complex is preferable to that of $7 \mathbf{a}$ (anti-parallel) $-\mathrm{Ag}^{+}$picrate complex.

Figure 5 shows conformations of (a) 7a (parallel) $-\mathrm{Pb}^{2+}$ and (b) 7a (anti-parallel) $-\mathrm{Pb}^{2+}$ picrate complexes obtained by the same method as for $\mathbf{7 a}-\mathrm{Ag}^{+}$picrate complex. Non-bonded distances between two methoxyphenyl groups and two diethylaminophenyl groups of 7a (parallel) $-\mathrm{Pb}^{2+}$ picrate complex are 4.13 and $4.51 \AA$, respectively, whereas those between two groups bonded to

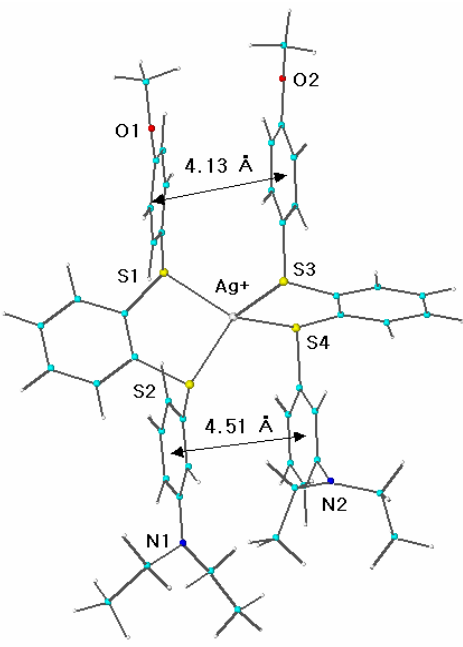

(a)

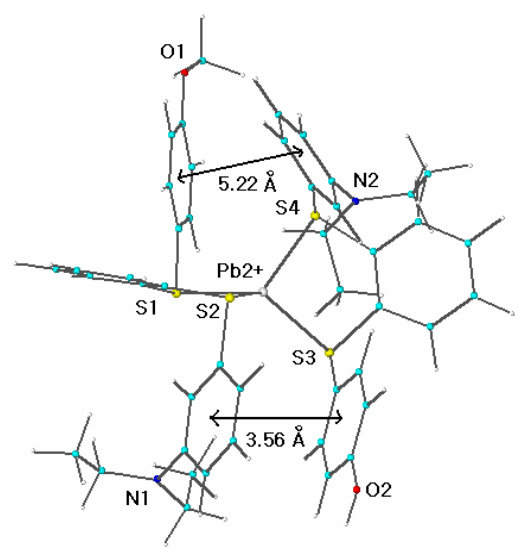

(b)

Figure 5. Molecular mechanics-calculated conformations of (a) 7a (parallel) $-\mathrm{Pb}^{2+}$ and (b) 7a (anti-parallel) $-\mathrm{Pb}^{2+}$ picrate complexes.

$\mathrm{S} 1$ and $\mathrm{S} 4$, and $\mathrm{S} 2$ and $\mathrm{S} 3$ of 7a (anti-parallel) $-\mathrm{Ag}^{+}$picrate complex are 5.22 and 3.56 , respectively. The calculated HOMO -LUMO interaction energies between $7 \mathbf{a}$ and $\mathrm{Pb}^{2+}$ picrate and the thermodynamic energies of the $7 \mathbf{a}$ and $\mathrm{Pb}^{2+}$ picrate complexes are summarized in Table 4 . The data show that the 7a (anti-parallel) $-\mathrm{Pb}^{2+}$ picrate complex has smaller HOMO - LUMO interaction energies than the 7a (parallel) $-\mathrm{Ag}^{+}$picrate complex by $2.9 \mathrm{eV}$ for $\alpha$-spin and $2.2 \mathrm{eV}$ for $\beta$-spin. The former also has a lower thermodynamic energy than the latter by $220 \mathrm{kcal} / \mathrm{mol}$. Consequently, it is conceivable that the formation of $7 \mathbf{a}$ (anti-parallel) $-\mathrm{Pb}^{2+}$ picrate complex is preferable to that of $7 \mathbf{a}$ (parallel) $-\mathrm{Pb}^{2+}$ picrate complex. 
Although the HOMO - LUMO interaction energy of the 7a (anti-parallel) $-\mathrm{Pb}^{2+}$ picrate complex is smaller than that of the 7a (parallel) $-\mathrm{Ag}^{+}$picrate complex, the latter shows a lower thermodynamic energy compared with that of the former, which may be reflected in the higher extractive ability of $7 \mathbf{a}$ toward $\mathrm{Ag}^{+}$ion compared with $\mathrm{Pb}^{2+}$ ion. The different tendencies of $7 \mathbf{a}$ and 13a with regard to complexing $\mathrm{Ag}^{+}$and $\mathrm{Pb}^{2+}$ ions are envisaged to be due to the presence of the bulky diisopropylamino group as a substituent which makes two molecules of 13a interact with $\mathrm{Pb}^{2+}$ ion to form a T-stacking complex so that the interaction energy between the HOMO of 13a and the LUMO of $\mathrm{Pb}^{2+}$ ion becomes drastically smaller compared with those between the HOMO - LUMO of other host and guest pairs and the complex becomes remarkably stable.

Compounds $\mathbf{7 j}$ and $\mathbf{7 m}$ having an aza-18-crown-6 moiety, respectively showed almost the same extractive abilities (67 and $66 \%$, respectively) as that of 13a toward $\mathrm{Pb}^{2+}$ ion. Surprisingly, aza-15-crown-5 and aza-18-crown-6, tethered sulfur-containing lariats at nitrogen atoms, have been seldom reported ${ }^{16}$ despite the existence of numerous studies of other types of lariats. Examination of the molecular mechanics calculations on $\mathbf{7 j}$ showed that a structure where the pendent arm is directed away from the azacrown has the lowest energy $(\mathrm{E}=38.06 \mathrm{kcal} / \mathrm{mol})$ (Figure 6, (a)). In this regard, the conformation is similar to the X-ray crystal structure of 14b (Figure 1). The preparation of a single crystal for X-ray crystallography of $\mathbf{7 j}-\mathrm{Pb}^{2+}$ complex was unsuccessful. However, the molecular mechanics calculations indicate that the interactions of a $\mathrm{Pb}^{2+}$ ion with two sulfur and three oxygen atoms of one molecule of aza-18-crown- 6 leads to a bent-type complex, which is the most stable complex having $\mathrm{E}=29.76 \mathrm{kcal} / \mathrm{mol}$ (Figure 6, (b)). A sandwich-type complex in which two ligands accommodate a $\mathrm{Pb}^{2+}$ ion between two lariats of $7 \mathbf{j}$ requires a higher energy by ca. $10 \mathrm{kcal} / \mathrm{mol}(\mathrm{E}=39.63 \mathrm{kcal} / \mathrm{mol})$ (Figure $6,(\mathrm{c}))$. The increase in the extractive abilities of $\mathbf{7 j}$ and $\mathbf{7 m}$ toward $\mathrm{Ag}^{+}$ion (40 and $24 \%$, respectively) compared with that of 13a (9\%) may be ascribed to the oxygen atoms comprising aza-18-crown-6. Surprisingly, compound 18a showed a very high selectivity toward $\mathrm{Ag}^{+}$ion $(86 \%)$, whereas its selectivity toward $\mathrm{Pb}^{2+}$ ion was comparable with those of 7e-f. It is envisaged that two lariats, i.e., 3-[2-(4methoxyphenylthio)-phenylthio]phenyl moieties, tethered

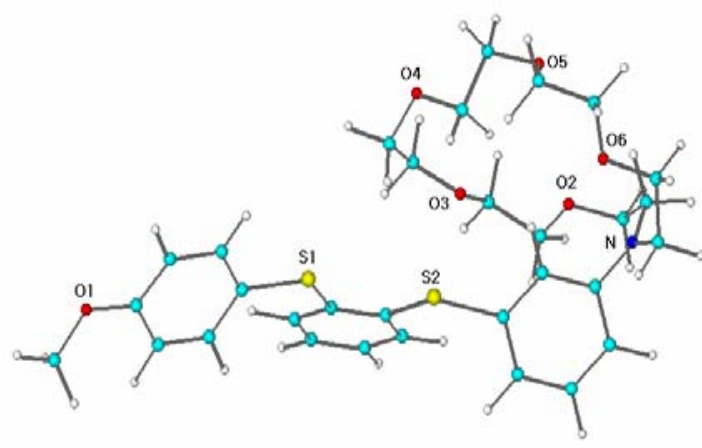

(a)

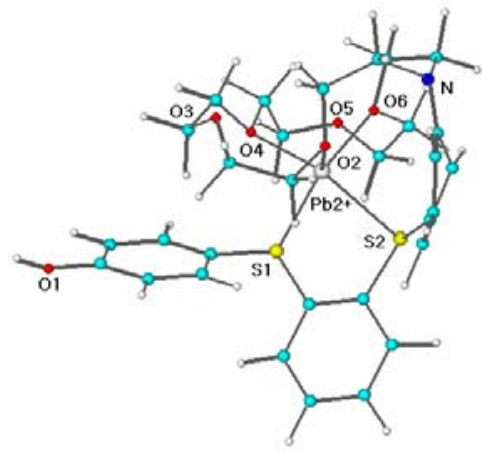

(b) 


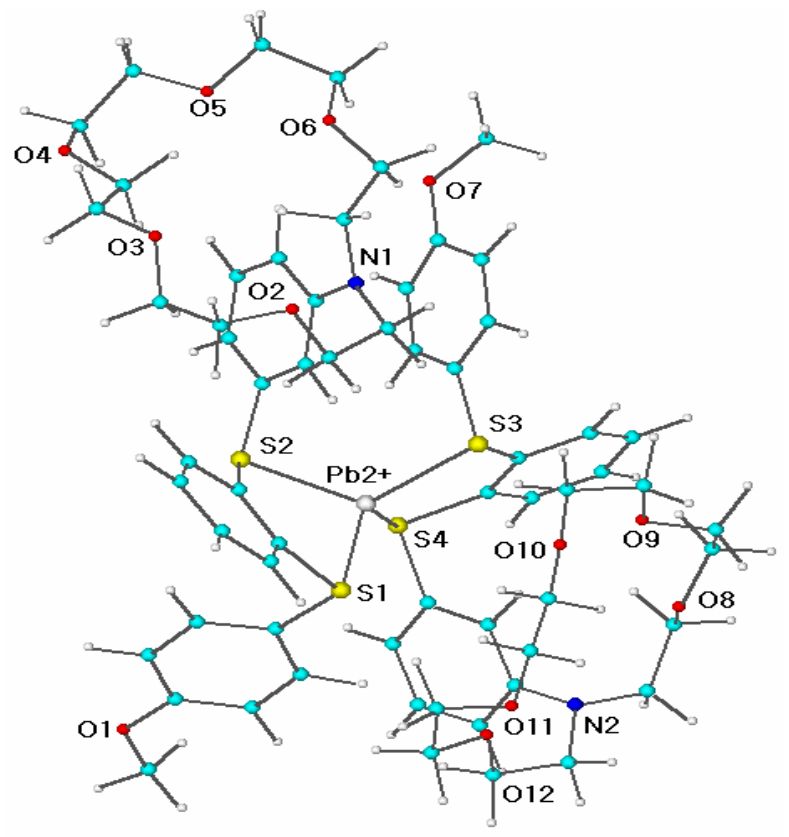

(c)

Figure 6. Molecular mechanics-calculated conformations of (a) the uncoordinated ligand $\mathbf{7 j}$, (b) the bent-type and (c) the sandwich-type $7 \mathbf{j}-\mathrm{Pb}^{2+}$ picrate complexes.

at the nitrogen of 7,16-diaza-18-crown-6, produce a strong interaction with an $\mathrm{Ag}^{+}$ion (Figure 7, (b)), whereas the lariats were directed away from the cavity (Figure 7, (a)) as for 7a, 7e-f, or 7h in the presence of $\mathrm{Pb}^{2+}$ ion which results in low extractive ability (12\%).

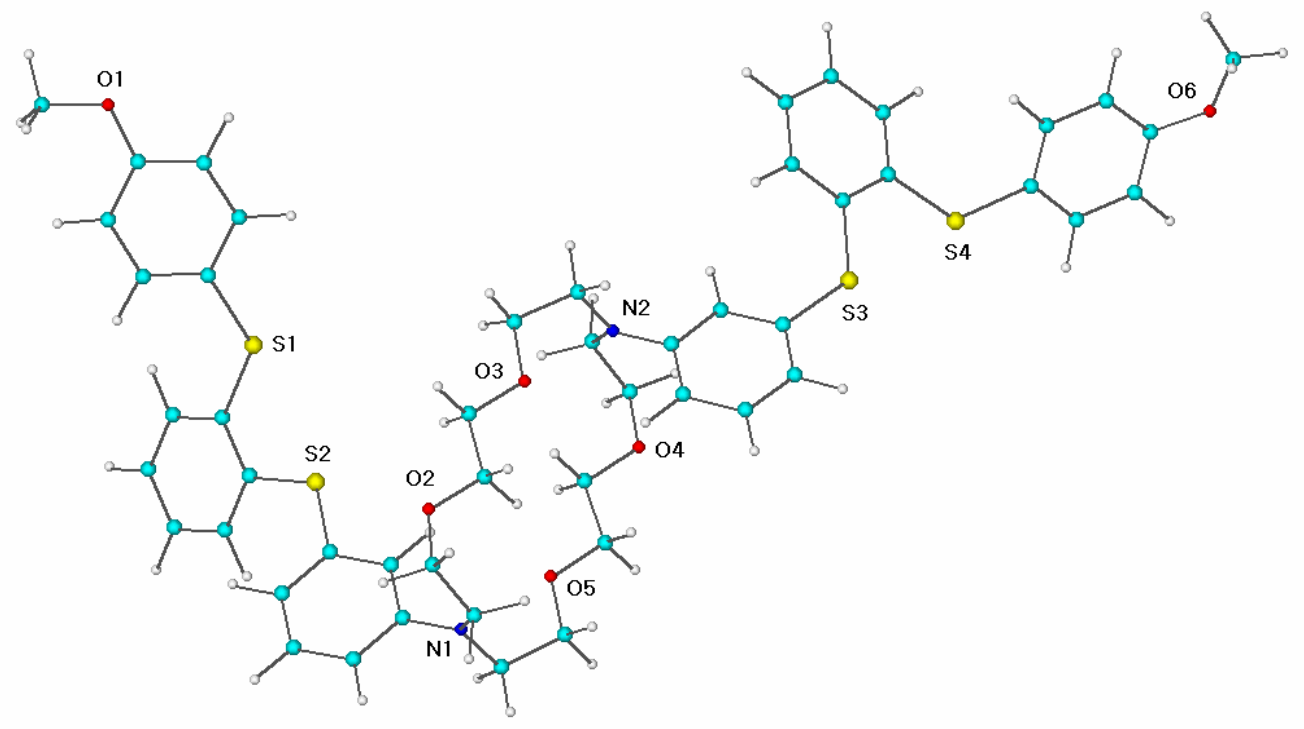


(a)

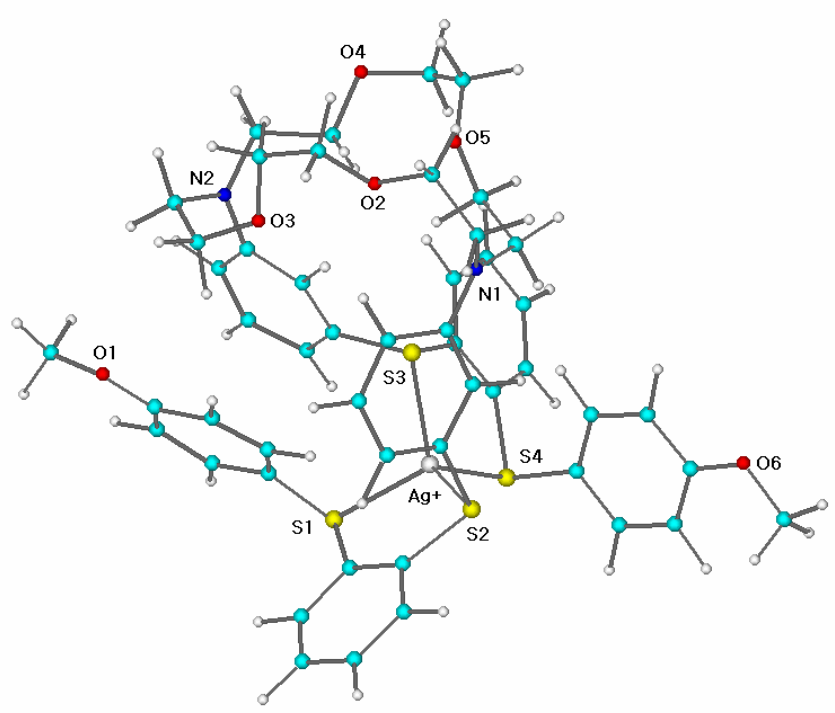

(b)

Figure 7. Molecular mechanics-calculated conformations of (a) the uncoordinated ligand 18a and (b) the 18a- $\mathrm{Ag}^{+}$picrate complex.

\section{(b) Job plot of 7a}

Nine different concentrations of $\mathbf{7 a}$ in $\mathrm{CHCl}_{3}$ and the same number of differing concentrations of silver picrate were prepared. A Jobs plot was obtained by mixing five milliliters of two different solutions making up $2.4 \times 10^{-4} \mathrm{M}$. Figure 6 shows that the highest absorbance was obtained when $1.6 \times 10^{-4} \mathrm{M}$ of $7 \mathrm{a}$ was mixed with $8 \times 10^{-5} \mathrm{M}$ of aqueous silver picrate. Furthermore, the complex obtained from the chloroform layer showed a mass number $(\mathrm{m} / \mathrm{z})$ of 899.82 on the MALDI-TOF spectrum, corresponding to the molecular weight of a complex consisting of two molecules of $7 \mathbf{a}$ and an $\mathrm{Ag}^{+}$ion. 


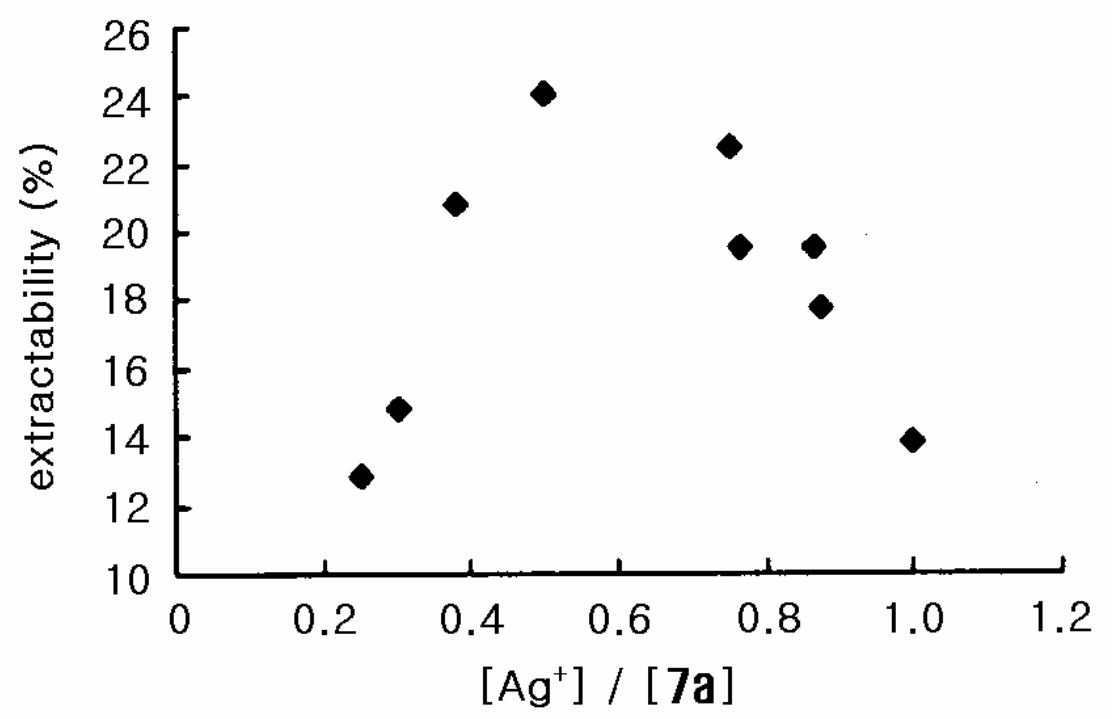

Figure 8. Extractability of $7 \mathbf{a}$ for $\mathrm{Ag}^{+}$ion versus the mole fraction $\left[\mathrm{Ag}^{+}\right] /[7 \mathbf{a}]$.

(c) ${ }^{1} \mathrm{H}$ NMR study of the complexation of $7 \mathbf{m}$ with $\mathrm{Ag}^{+}$and $\mathrm{Pb}^{2+}$ ions

The ${ }^{1} \mathrm{H}$ NMR spectrum $\left(300 \mathrm{MHz}, \mathrm{CDCl}_{3}\right.$ ) of $\mathbf{7 m}$ was compared with those of the $\mathbf{7 m}-\mathrm{Ag}^{+}$and the $\mathbf{7 m}-\mathrm{Pb}^{2+}$ complexes. The comparison of the intensities of the aromatic protons of picrate appearing at $8.72 \mathrm{ppm}$ with those of the methyl protons of the isopropyl group appearing at 1.35 ppm indicates the efficiency of the formation of the complex under the conditions in which the extractability experiment was performed. The ${ }^{1} \mathrm{H}$ NMR spectroscopic data showed 33 and 79\% complexations toward $\mathrm{Ag}^{+}$and $\mathrm{Pb}^{2+}$ ions, respectively. These values are a little higher than 24 and $66 \%$, respectively, which were obtained from the extractability experiments.

A noteworthy feature is that there is little difference in the shape of a multiplet appearing at 3.55 - $3.67 \mathrm{ppm}$, assigned to 24 methylene protons of $\mathbf{7 m}$ and $\mathbf{7 m}-\mathrm{Ag}^{+}$complex, but significantly different shapes were observed in the multiplets of the aromatic proton signals. In contrast, the $7 \mathrm{~m}-\mathrm{Pb}^{2+}$ complex exhibited a multiplet in the range of $3.32-3.85 \mathrm{ppm}$. The range observed from the latter complex is wider than that observed from the $7 \mathbf{m}-\mathrm{Ag}^{+}$complex. Furthermore, the shape differed considerably from that of the $7 \mathbf{m}-\mathrm{Ag}^{+}$complex but the shapes of the aromatic proton signals of the $7 \mathbf{m}-\mathrm{Ag}^{+}$and $7 \mathbf{m}-\mathrm{Pb}^{2+}$ complexes appeared similar. The results indicate that $\mathrm{Ag}^{+}$ion does not interact strongly with aza-18-crown-6 ring but $\mathrm{Pb}^{2+}$ interacts strongly with the same ring. This view is in good agreement with the similar extractabilities of $\mathbf{7 a}, \mathbf{7 h}$, and $\mathbf{7} \mathbf{m}$ toward $\mathrm{Ag}^{+}$ion (Table 2) and the large difference in the extractabilities between $\mathbf{7 a}$ or $\mathbf{7 h}$ and $\mathbf{7 m}$ toward $\mathrm{Pb}^{2+}$ ion.

In summary, 5-arylthianthrenium perchlorates 2 reacted with secondary alkylamines in the presence of LDA in THF at reflux temperature to give 2-(arylthio)-3'-(dialkylamino)diphenyl sulfides 7 as major products via a benzyne intermediate. In addition, 2-(arylthio)-2'(dialkylamino)diphenyl sulfides 8 and thianthrene were formed depending on the structures of amines employed and the concentrations of LDA. The affinity of selected metal cations to 
sulfides $7 \mathbf{a}, 7 \mathbf{7}-\mathbf{f}, 7 \mathbf{h}, \mathbf{7 j}, \mathbf{7 m}, \mathbf{1 0}, \mathbf{1 3 a}$, and $\mathbf{1 8 a}$ was examined by an extraction method. Compounds 13a, 7j, $7 \mathbf{m}$ showed $66-67 \%$ extractive abilities toward $\mathrm{Pb}^{2+}$ ions, and compound 18a showed $86 \%$ extractive ability toward $\mathrm{Ag}^{+}$ions.

\section{Experimental Section}

General Procedures. The ${ }^{1} \mathrm{H}$ and ${ }^{13} \mathrm{C}$ NMR spectra were recorded $300 \mathrm{MHz}$ and $75 \mathrm{MHz}$, respectively in $\mathrm{CDCl}_{3}$ or DMSO- $d_{6}$ solution containing $\mathrm{Me}_{4} \mathrm{Si}$ as internal standard. IR spectra were recorded in $\mathrm{KBr}$ or film on $\mathrm{KBr}$ plates. Elemental analyses were determined by the Korea Basic Science Center. MALDI-TOF and FAB mass spectra were determined by National Center for Inter-University Research Facilities. Column chromatography was performed using silica gel (230-400 mesh, Merck). Melting points were measured on Fisher-Jones melting point apparatus and uncorrected. 5-Arylthianthrenium perchlorates (2) were prepared by the literature methods. ${ }^{2}$ Amines were dried as reported in the literature. ${ }^{17}$

\section{General procedure for the reactions of $\mathbf{2}$ with alkylamines}

(a) To a solution of alkylamine in THF $(20 \mathrm{~mL})$ was added NaH $(1.64 \mathrm{mmol})$ under nitrogen atmosphere. The solution was stirred for $20 \mathrm{~min}$ at room temperature, followed by the addition of 2. The mixture was additionally stirred for an appropriate hour at reflux. Removal of the solvent in vacuo gave a residue, which was chromatographed on silica gel $(7 \times 1.5 \mathrm{~cm})$. Elution with a mixture of EtOAc and hexane (1:9) gave thianthrene (9) and desired compounds 7 and 8. Quantities of $\mathbf{2}$ and $\mathrm{NaH}$, and yields of $\mathbf{7 , 8}$, and $\mathbf{9}$ are summarized in Table 1.

(b) To a solution of alkylamine in THF $(50 \mathrm{~mL})$ was added 2 . The mixture was heated at reflux under nitrogen atmosphere, followed by the addition of $0.3 \mathrm{~mL}(0.6 \mathrm{mmol})$ of LDA ( $2 \mathrm{M}$, hexane) six to eight times at the intervals of 40 min using a hypodermic syringe. Removal of the solvent in vacuo gave a residue, which was chromatographed on silica gel $(7 \times 1.5 \mathrm{~cm})$ as described in (a).

3'-(Diethylamino)-2-(4-methoxyphenylthio)diphenyl sulfide (7a). Oily liquid; ${ }^{1} \mathrm{H}$ NMR $\delta 1.17$ (t, $J=7.1 \mathrm{~Hz}, 6 \mathrm{H}), 3.36(\mathrm{q}, J=7.0 \mathrm{~Hz}, 4 \mathrm{H}), 3.86(\mathrm{~s}, 3 \mathrm{H}), 6.57$ (dd, $J=8.4,2.5 \mathrm{~Hz}, 1 \mathrm{H}), 6.62(\mathrm{~d}$, $J=7.5 \mathrm{~Hz}, 1 \mathrm{H}), 6.63(\mathrm{~s}, 1 \mathrm{H}), 6.86-6.92(\mathrm{~m}, 3 \mathrm{H}), 7.00-7.03(\mathrm{~m}, 2 \mathrm{H}), 7.14(\mathrm{t}, J=8.1 \mathrm{~Hz}, 1 \mathrm{H})$, 7.19-7.22 (m, 1H), $7.41(\mathrm{~d}, J=8.4 \mathrm{~Hz}, 2 \mathrm{H}) ;{ }^{13} \mathrm{C}$ NMR $\delta 12.5,44.3,55.3,110.8,114.2,115.1$, 118.0, 123.6, 126.1, 127.3, 128.3, 130.0, 131.7, 134.7, 135.1, 135.8, 140.5, 148.4, 160.0; IR (neat) 3048, 2968, 1589, 1489, 1434, 1347, 1251, $1171 \mathrm{~cm}^{-1}$; MS (EI) $m / z 395\left(\mathrm{M}^{+}, 55\right), 380$ (100), 256 (8), 216 (24), 190 (28). Anal. Calcd for $\mathrm{C}_{23} \mathrm{H}_{25} \mathrm{NOS}_{2}$ : C, 69.83; H, 6.37; N, 3.54; S, 16.21. Found: C, 69.69; H, 6.29; N, 3.49; S, 16.32.

2-(4-Methoxyphenylthio)-3'-(pentylamino)diphenyl sulfide (7b). Oily liquid; ${ }^{1} \mathrm{H}$ NMR $\delta 0.93$ $(\mathrm{m}, 3 \mathrm{H}), 1.34-1.61(\mathrm{~m}, 6 \mathrm{H}), 3.08(\mathrm{t}, J=7.1 \mathrm{~Hz}, 2 \mathrm{H}), 3.85(\mathrm{~s}, 3 \mathrm{H}), 6.52(\mathrm{dd}, J=8.2,1.6 \mathrm{~Hz}, 1 \mathrm{H})$, $6.62(\mathrm{t}, J=2.0 \mathrm{~Hz}, 1 \mathrm{H}), 6.68(\mathrm{dd}, J=7.8,1.7 \mathrm{~Hz}, 1 \mathrm{H}), 6.89-6.95(\mathrm{~m}, 3 \mathrm{H}), 7.07(\mathrm{~m}, 2 \mathrm{H}), 7.14(\mathrm{t}$, $J=7.9 \mathrm{~Hz}, 1 \mathrm{H}), 7.24(\mathrm{~m}, 1 \mathrm{H}), 7.45(\mathrm{~d}, J=6.7 \mathrm{~Hz}, 2 \mathrm{H})$, A NH proton signal is invisible; ${ }^{13} \mathrm{C}$ 
NMR $\delta 14.5,22.9,29.6,29.7,44.3,55.7,112.2,115.3,115.6,120.1,124.1,126.6,127.9,128.9$, $130.3,132.5,134.9,135.8,136.2,141.2,149.7,160.4$; IR (neat) 3400, 2912, 1582, 1482, 1434 , 1280, 1250, 1160, $1027 \mathrm{~cm}^{-1}$; MS (EI) m/z 409 (M+, 50), 352 (5), 270 (14), 244 (12), 216 (100), 176 (34). Anal. Calcd for $\mathrm{C}_{24} \mathrm{H}_{27} \mathrm{NOS}_{2}$ : C, 70.21; H, 6.60; N, 3.68; S, 15.61. Found: C, 70.32; H, $6.70 ; \mathrm{N}, 3.40 ; \mathrm{S}, 15.67$.

2-(4-Methoxyphenylthio)-3'-(p-toluidino)diphenyl sulfide (7c). Oily liquid; ${ }^{1} \mathrm{H}$ NMR $\delta 2.19$ (s, $3 \mathrm{H}), 3.72(\mathrm{~s}, 3 \mathrm{H}), 5.53(\mathrm{~s}, 1 \mathrm{H}), 6.73-6.87(\mathrm{~m}, 8 \mathrm{H}), 6.94-7.00(\mathrm{~m}, 4 \mathrm{H}), 7.06(\mathrm{t}, J=7.8 \mathrm{~Hz}, 1 \mathrm{H})$, $7.19(\mathrm{~d}, J=7.9 \mathrm{~Hz}, 1 \mathrm{H}), 7.30(\mathrm{~d}, J=8.6 \mathrm{~Hz}, 2 \mathrm{H}) ;{ }^{13} \mathrm{C} \mathrm{NMR} \delta 29.7,55.4,115.0,115.2,117.7$, $119.3,121.8,123.4,126.1,128.1,128.2,129.8,129.9,131.3,133.0,133.2,136.1,136.4,139.6$, 142.2, 144.9, 160.1; IR (neat) 3376, 3040, 2936, 1578, 1506, 1483, 1435, 1280, 1250, $1026 \mathrm{~cm}^{-1}$; MS (EI) $m / z 429\left(\mathrm{M}^{+}, 100\right), 214$ (24), 106(90). Anal. Calcd for $\mathrm{C}_{26} \mathrm{H}_{23} \mathrm{NOS}_{2}$ : C, 72.69; H, 5.40; N, 3.26; S, 14.92. Found: C, 72.58; H, 5.43; N, 3.29; S, 14.85 .

3'-[(2-Aminoethyl)amino]-2-(4-methoxyphenylthio)diphenyl sulfide (7d). Oily liquid; ${ }^{1} \mathrm{H}$ NMR $\delta 2.66(\mathrm{br}, \mathrm{s}, 2 \mathrm{H}), 2.95(\mathrm{t}, J=5.3 \mathrm{~Hz}, 2 \mathrm{H}), 3.19(\mathrm{t}, J=5.4 \mathrm{~Hz}, 2 \mathrm{H}), 3.85(\mathrm{~s}, 3 \mathrm{H}), 6.56(\mathrm{~d}, J$ $=7.4 \mathrm{~Hz}, 1 \mathrm{H}), 6.65(\mathrm{~s}, 1 \mathrm{H}), 6.68(\mathrm{~d}, J=7.6 \mathrm{~Hz}, 1 \mathrm{H}), 6.89-6.96(\mathrm{~m}, 3 \mathrm{H}), 7.05-7.16(\mathrm{~m}, 3 \mathrm{H}), 7.25$ $(\mathrm{m}, 1 \mathrm{H}), 7.44(\mathrm{dd}, J=6.7,2.1 \mathrm{~Hz}, 2 \mathrm{H})$, A NH proton signal is invisible; ${ }^{13} \mathrm{C}$ NMR $\delta 40.9,45.4$, 55.8, 112.4, 115.2, 115.6, 120.2, 123.8, 126.6, 128.1, 128.8, 130.5, 132.7, 134.3, 136.0, 136.3, 141.4, 149.3, 160.5; IR (neat) 3353, 3053, 2935, 1591, 1490, 1247, $1031 \mathrm{~cm}^{-1}$; MS (EI) $\mathrm{m} / z 339$ $\left(\mathrm{M}^{+}, 43\right), 215$ (6), 200 (76). Anal. Calcd for $\mathrm{C}_{21} \mathrm{H}_{22} \mathrm{~N}_{2} \mathrm{OS}_{2}$ : C, 65.93; H, 5.80; N, 7.32; S, 16.76. Found: C, 65.89; H, 5.83; N, 7.25; S, 16.63.

2-(4-Methoxyphenylthio)-3'-(dipropylamino)diphenyl sulfide (7e). Oily liquid; ${ }^{1} \mathrm{H}$ NMR $\delta$ 0.85 (t, $J=7.4 \mathrm{~Hz}, 6 \mathrm{H}), 1.54$ (sextet, $J=7.6 \mathrm{~Hz}, 4 \mathrm{H}), 3.15$ (t, $J=7.6 \mathrm{~Hz}, 4 \mathrm{H}), 3.79$ (s, 3H), 6.496.54 (overlap of s and dd, 2H), $6.60(\mathrm{~d}, J=7.7 \mathrm{~Hz}, 1 \mathrm{H}), 6.84-6.87(\mathrm{~m}, 1 \mathrm{H}), 6.90(\mathrm{~d}, J=8.6 \mathrm{~Hz}$, 2H), 7.01-7.05 (m, 2H), $7.12(\mathrm{t}, J=7.8 \mathrm{~Hz}, 1 \mathrm{H}), 7.24-7.27(\mathrm{~m}, 1 \mathrm{H}), 7.41(\mathrm{~d}, J=8.9 \mathrm{~Hz}, 2 \mathrm{H}) ;{ }^{13} \mathrm{C}$ NMR $\delta 11.9,20.8,53.3,55.8,110.9,113.9,115.6,117.8,124.0,126.5,128.1,128.5,130.3$, 133.0, 134.4, 135.9, 136.5, 141.9, 149.3, 160.5; IR (neat) 3040, 2944, 2872, 1579, 1483, 1434, 1355, 1282, 1246, $1029 \mathrm{~cm}^{-1}$; MS (EI) $m / z 423\left(\mathrm{M}^{+}, 32\right), 394$ (100), 216 (37). Anal. Calcd for $\mathrm{C}_{25} \mathrm{H}_{29} \mathrm{NOS}_{2}$ : C, 70.88; H, 6.90; N, 3.31; S, 15.14. Found: C, 70.73; H, 6.82; N, 3.15; S, 15.29.

3'-(Dibutylamino)-2-(4-methoxyphenylthio)diphenyl sulfide (7f). Oily liquid; ${ }^{1} \mathrm{H}$ NMR $\delta 0.90$ (t, $J=7.5 \mathrm{~Hz}, 6 \mathrm{H}), 1.28(\mathrm{~m}, 4 \mathrm{H}), 1.49(\mathrm{~m}, 4 \mathrm{H}), 3.19(\mathrm{t}, J=7.7 \mathrm{~Hz}, 4 \mathrm{H}), 3.83(\mathrm{~m}, 3 \mathrm{H}), 6.50-6.53$ (overlap of s and dd, 2H), $6.61(\mathrm{~d}, J=7.9 \mathrm{~Hz}, 1 \mathrm{H}), 6.86(\mathrm{~m}, 1 \mathrm{H}), 6.92(\mathrm{~d}, J=8.8 \mathrm{~Hz}, 2 \mathrm{H}), 7.05$ $(\mathrm{m}, 2 \mathrm{H}), 7.12(\mathrm{t}, J=7.6 \mathrm{~Hz}, 1 \mathrm{H}), 7.27(\mathrm{~m}, 1 \mathrm{H}), 7.42(\mathrm{~d}, J=8.7 \mathrm{~Hz}, 2 \mathrm{H}) ;{ }^{13} \mathrm{C} \mathrm{NMR} \delta 14.4,20.7$, 29.8, 51.2, 55.8, 110.8, 113.8, 115.5, 117.7, 124.0, 126.4, 128.1, 128.5, 130.2, 132.9, 134.4, 135.9, 136.4, 141.8, 149.2, 160.5; MS (EI) m/z $451\left(\mathrm{M}^{+}, 37\right), 408$ (100), 366 (41), 216 (51), 183 (29). Anal. Calcd for $\mathrm{C}_{27} \mathrm{H}_{33} \mathrm{NOS}_{2}$ : C, 71.80; H, 7.36; N, 3.10; S, 14.20. Found: C, 71.66; H, 7.27; N, 2.98; S, 14.26.

3'-(Morpholino)-2-(4-methoxyphenylthio)diphenyl sulfide (7g). Oily liquid; ${ }^{1} \mathrm{H}$ NMR $\delta 3.04$ (t, $J=4.8 \mathrm{~Hz}, 4 \mathrm{H}), 3.72(\mathrm{~m}, 7 \mathrm{H}), 6.71-6.74(\mathrm{~m}, 2 \mathrm{H}), 6.81-6.84(\mathrm{~m}, 4 \mathrm{H}), 6.95-6.99(\mathrm{~m}, 2 \mathrm{H}), 7.10-$ $7.16(\mathrm{~m}, 2 \mathrm{H}), 7.33(\mathrm{~d}, J=8.9 \mathrm{~Hz}, 2 \mathrm{H}) ;{ }^{13} \mathrm{C} \mathrm{NMR} \delta 48.8,55.1,66.6,114.2,114.9,117.6,122.1$, $123.3,125.9,127.6,128.2,129.6,132.0,133.7,135.5,135.7,141.0,151.7,159.9$; IR (neat) 
3040, 2944, 2816, 1582, 1565, 1478, 1435, 1251, 1168, $1118 \mathrm{~cm}^{-1}$; MS (EI) $\mathrm{m} / z 409\left(\mathrm{M}^{+}, 100\right)$, 351 (23), 270 (11), 242 (9), 216 (10), 200 (12), 184 (37). Anal. Calcd for $\mathrm{C}_{23} \mathrm{H}_{23} \mathrm{NO}_{2} \mathrm{~S}_{2}$ : C, 67.45; H, 5.66; N, 3.42; S, 15.66. Found: C, 67.25; H, 5.58; N, 3.39; S, 15.57.

2-(4-Methoxyphenylthio)-3'-(piperidino)diphenyl sulfide (7h). Oily liquid; ${ }^{1} \mathrm{H}$ NMR $\delta 1.55$ $(\mathrm{m}, 2 \mathrm{H}), 1.65(\mathrm{~m}, 4 \mathrm{H}), 3.11(\mathrm{t}, J=5.4 \mathrm{~Hz}, 4 \mathrm{H}), 3.78(\mathrm{~s}, 3 \mathrm{H}), 6.77(\mathrm{~d}, J=7.6 \mathrm{~Hz}, 1 \mathrm{H}), 6.82(\mathrm{dd}, J$ $=8.2,2.1 \mathrm{~Hz}, 1 \mathrm{H}), 6.89(\mathrm{~m}, 3 \mathrm{H}), 6.97(\mathrm{~s}, 1 \mathrm{H}), 6.99-7.05(\mathrm{~m}, 2 \mathrm{H}), 7.13-7.21(\mathrm{~m}, 2 \mathrm{H}), 7.41-7.38$ $(\mathrm{d}, J=8.7 \mathrm{~Hz}, 2 \mathrm{H}) ;{ }^{13} \mathrm{C}$ NMR $\delta 24.7,26.2,50.7,55.8,115.6,115.9,119.5,122.3,124.1,126.7$, 127.9, 129.0, 130.2, 132.1, 135.3, 135.5, 136.2, 140.8, 153.2, 160.5; IR (neat) 3048, 2920, 2824, 1578, 1475, 1438, 1282, 1248, $1024 \mathrm{~cm}^{-1}$; MS (EI) m/z $407\left(\mathrm{M}^{+}, 100\right), 268$ (33), 216 (13), 184 (29). Anal. Calcd for $\mathrm{C}_{24} \mathrm{H}_{25} \mathrm{NOS}_{2}$ : C, 70.72; H, 6.18; N, 3.44; S, 15.73. Found: C, 70.59; H, $6.23 ; \mathrm{N}, 3.27 ; \mathrm{S}, 15.85$.

13-[3-\{2-(4-Methoxyphenylthio)phenylthio\}phenyl]-1,4,7,10-tetraoxa-13-azacyclopentadecane (7i). Oily liquid; ${ }^{1} \mathrm{H}$ NMR $\delta 3.55(\mathrm{~m}, 4 \mathrm{H}), 3.63(\mathrm{~m}, 16 \mathrm{H}), 3.83(\mathrm{~s}, 3 \mathrm{H}), 6.63(\mathrm{~m}, 3 \mathrm{H}), 6.91(\mathrm{~m}, 3 \mathrm{H}), 7.05$ (m, 2H), 7.15-7.26 (m, 2H), 7.43 (d, $J=8.9 \mathrm{~Hz}, 2 \mathrm{H})$; IR (neat) 2864, 1579, 1483, 1435, 1373, 1346, 1282, 1245, 1115, $1027 \mathrm{~cm}^{-1}$. Anal. Calcd for $\mathrm{C}_{29} \mathrm{H}_{35} \mathrm{NO}_{5} \mathrm{~S}_{2}$ : C, 64.30; H, 6.51; N, 2.59; S, 11.84. Found: C, 64.37; H, 6.39; N, 2.46; S, 11.75.

16-[3-\{2-(4-Methoxyphenylthio)phenylthio\}phenyl]-1,4,7,10,13-pentaoxa-16-azacyclooctadecane (7j). Oily liquid; ${ }^{1} \mathrm{H}$ NMR $\delta 3.48-3.58(\mathrm{~m}, 24 \mathrm{H}), 3.73(\mathrm{~s}, 3 \mathrm{H}), 6.53(\mathrm{~m}, 3 \mathrm{H}), 6.79(\mathrm{~m}, 1 \mathrm{H}), 6.38(\mathrm{dd}, J=$ 6.7, 2.2 Hz, 2H), 6.94-6.98 (m, 2H), $7.06(\mathrm{t}, J=7.9 \mathrm{~Hz}, 1 \mathrm{H}), 7.13(\mathrm{~m}, 1 \mathrm{H}), 7.33$ (dd, $J=6.7,2.2$ $\mathrm{Hz}, 2 \mathrm{H}$ ); IR (neat) 3040, 2848, 1579, 1482, 1435, 1344, $1280 \mathrm{~cm}^{-1}$. Anal. Calcd for $\mathrm{C}_{31} \mathrm{H}_{39} \mathrm{NO}_{6} \mathrm{~S}_{2}$ : C, 64.68; H, 5.08; N, 2.43; S, 11.14. Found: C, 64.54; H, 4.99; N, 2.33; S, 11.26.

13-[3-\{2-(2,4-Dimethoxyphenylthio)phenylthio\}phenyl]-1,4,7,10-tetraoxa-13-azacyclopentadecane (7k). Oily liquid; ${ }^{1} \mathrm{H}$ NMR $\delta 3.23(\mathrm{t}, J=4.67 \mathrm{~Hz}, 4 \mathrm{H}), 3.38(\mathrm{t}, J=4.8 \mathrm{~Hz}, 4 \mathrm{H}), 3.47(\mathrm{~m}, 4 \mathrm{H}), 3.55(\mathrm{~m}$, 4H), $3.62(\mathrm{~m}, 4 \mathrm{H}), 3.71(\mathrm{~s}, 3 \mathrm{H}), 3.77(\mathrm{~s}, 3 \mathrm{H}), 6.45(\mathrm{~d}, J=8.8 \mathrm{~Hz}, 1 \mathrm{H}), 6.47(\mathrm{~s}, 1 \mathrm{H}), 6.69(\mathrm{~d}, J=$ $7.8 \mathrm{~Hz}, 1 \mathrm{H}), 6.92-7.01$ (m, 5H), 7.16-7.25 (m, 3H); IR (neat) 2960, 1596, 1497, 1475, 1386, 1273, 1245, 1190, 1053, 1011, $784 \mathrm{~cm}^{-1}$. Anal. Calcd for $\mathrm{C}_{30} \mathrm{H}_{37} \mathrm{NO}_{6} \mathrm{~S}_{2}: \mathrm{C}, 63.02 ; \mathrm{H}, 6.52 ; \mathrm{N}$, 2.45; S, 11.21. Found: C, 62.87; H, 4.64; N, 2.35; S, 11.37.

16-[3-\{2-(2,4-Dimethoxyphenylthio)phenylthio\}phenyl]-1,4,7,10,13-pentaoxa-16-azacyclooctadecane (7l). Oily liquid; ${ }^{1} \mathrm{H}$ NMR $\delta 3.51-3.59(\mathrm{~m}, 24 \mathrm{H}), 3.72(\mathrm{~s}, 3 \mathrm{H}), 3.76(\mathrm{~s}, 3 \mathrm{H}), 6.43-6.58(\mathrm{~m}, 5 \mathrm{H}), 6.72(\mathrm{~m}$, $1 \mathrm{H}), 6.97(\mathrm{~m}, 2 \mathrm{H}), 7.06(\mathrm{t}, J=7.9 \mathrm{~Hz}, 1 \mathrm{H}), 7.14(\mathrm{~m}, 1 \mathrm{H}), 7.25$ (d, $J=8.2 \mathrm{~Hz}, 1 \mathrm{H})$; IR (neat) 3296, 2912, 2208, 1616, 1568, 1488, 1459, 1276, 1248, 1212, 1177, 1136, 1043, 1017, 829, 809, $777 \mathrm{~cm}^{-1}$. Anal. Calcd for $\mathrm{C}_{32} \mathrm{H}_{41} \mathrm{NO}_{7} \mathrm{~S}_{2}: \mathrm{C}, 62.41 ; \mathrm{H}, 6.71 ; \mathrm{N}, 2.27 ; \mathrm{S}, 10.41$. Found: C, 62.53; $\mathrm{H}, 6.68 ; \mathrm{N}, 2.33 ; \mathrm{S}, 10.36$.

16-[3-\{2-(4-Isopropoxyphenylthio)phenylthio\}phenyl]-1,4,10,13-tetraoxa-7,16-diazacyclooctadecane (7m). Oily liquid; ${ }^{1} \mathrm{H}$ NMR $\delta 1.35(\mathrm{~d}, J=6.1 \mathrm{~Hz}, 6 \mathrm{H}), 3.55-3.67(\mathrm{~m}, 24 \mathrm{H}), 4.57$ (hept, $\left.J=6.1 \mathrm{~Hz}, 1 \mathrm{H}\right)$, $6.64(\mathrm{~m}, 3 \mathrm{H}), 6.89(\mathrm{~m}, 3 \mathrm{H}), 7.04(\mathrm{~m}, 2 \mathrm{H}), 7.14(\mathrm{t}, J=7.9 \mathrm{~Hz}, 1 \mathrm{H}), 7.21(\mathrm{~m}, 1 \mathrm{H}), 7.40(\mathrm{~d}, J=8.8$ $\mathrm{Hz}, 2 \mathrm{H}$ ); IR (neat) 2864, 1579, 1478, 1437, 1374, 1346, 1275, 1242, $1110 \mathrm{~cm}^{-1}$. Anal. Calcd for $\mathrm{C}_{33} \mathrm{H}_{43} \mathrm{NO}_{6} \mathrm{~S}_{2}$ : C, 64.57; H, 7.06; N, 2.28; S, 10.45. Found: C, 64.39; H, 6.87; N, 2.34; S, 10.69. 16-[3-\{2-(4-tert-Butyl-3-methoxyphenylthio)phenylthio\}phenyl]-1,4,7,10,13-pentaoxa-16azacyclo-octadecane (7n). Oily liquid; ${ }^{1} \mathrm{H}$ NMR $\delta 1.12(\mathrm{~s}, 9 \mathrm{H}), 3.54-3.68(\mathrm{~m}, 24 \mathrm{H}), 3.88$ (s, 
3H), 6.65-6.73 (m, 3H), 6.97 (m, 2H), 7.05-7.19 (m, 6H); IR (neat) 2944, 2856, 1579, 1478, 1442, 1392, $1107 \mathrm{~cm}^{-1}$. Anal. Calcd for $\mathrm{C}_{35} \mathrm{H}_{47} \mathrm{NO}_{6} \mathrm{~S}_{2}: \mathrm{C}, 65.49 ; \mathrm{H}, 7.38 ; \mathrm{N}, 2.18 ; \mathrm{S}, 9.99$. Found: C, 65.71; H, 7.28; N, 2.31; S, 9.92.

2'-(Diethylamino)-2-(4-methoxyphenylthio)diphenyl sulfide (8a). Oily liquid; ${ }^{1} \mathrm{H}$ NMR $\delta 1.00$ (t, $J=7.1 \mathrm{~Hz}, 6 \mathrm{H}), 3.05(\mathrm{q}, J=7.1 \mathrm{~Hz}, 4 \mathrm{H}), 3.75(\mathrm{~s}, 3 \mathrm{H}), 6.63(\mathrm{~d}, J=8.1 \mathrm{~Hz}, 1 \mathrm{H}), 6.72(\mathrm{~d}, J=$ $7.8 \mathrm{~Hz}, 1 \mathrm{H}), 6.83-6.89(\mathrm{~m}, 3 \mathrm{H}), 6.98-7.10(\mathrm{~m}, 4 \mathrm{H}), 7.35(\mathrm{~m}, 3 \mathrm{H}) ;{ }^{13} \mathrm{C} \mathrm{NMR} \delta 12.5,47.8,55.4$, $115.2,123.0,123.3,124.5,125.6,125.9,127.1$ (overlap of two carbons), 128.9, 130.6, 135.9, 136.2, 136.8, 145.7, 148.2, 160.3; IR (neat) 3051, 2969, 2930, 2833, 1585, 1491, 1441, 1368, 1247, 1174, $1031 \mathrm{~cm}^{-1}$; MS (EI) m/z 395 (M+, 100), 380 (42), 366 (19), 256 (9), 240 (27), 227 (66), 216 (22), 164 (55). Anal. Calcd for $\mathrm{C}_{23} \mathrm{H}_{25} \mathrm{NOS}_{2}$ : C, 69.83; H, 6.37; N, 3.54; S, 16.21. Found: C, 69.76; H, 6.28; N, 3.39; S, 16.33.

2'-(Morpholino)-2-(4-methoylphenylthio)diphenyl sulfide (8g). Oily liquid; ${ }^{1} \mathrm{H}$ NMR $\delta 3.03$ $(\mathrm{t}, J=4.8 \mathrm{~Hz}, 4 \mathrm{H}), 3.76(\mathrm{~m}, 7 \mathrm{H}), 6.68(\mathrm{dd}, J=7.8,1.3 \mathrm{~Hz}, 1 \mathrm{H}), 6.75(\mathrm{dd}, J=7.8,1.4 \mathrm{~Hz}, 1 \mathrm{H})$, 6.84-6.89 (m, 3H), 6.98-7.10 (m, 4H), 7.29-7.36 (m, 3H); ${ }^{13} \mathrm{C}$ NMR $\delta 52.5,55.8,67.8,115.6$, 120.4 , 123.3, 125.0, 126.2, 127.0, 127.8, 128.3, 129.4, 130.4, 133.2, 135.7, 137.1, 145.5, 150.3, 160.7; IR (neat) 3054, 2959, 2852, 1588, 1463, 1412, 1248, 1114, $1034 \mathrm{~cm}^{-1}$; MS (EI) $\mathrm{m} / z 409$ $\left(\mathrm{M}^{+}, 100\right), 350$ (30), 270 (23), 242 (75), 212 (36), 180 (80). Anal. Calcd for $\mathrm{C}_{23} \mathrm{H}_{23} \mathrm{NO}_{2} \mathrm{~S}_{2}$ : C, 67.45; H, 5.66; N, 3.42; S, 15.66. Found: C, 67.58; H, 5.59; N, 3.31; S, 15.64 .

2-(4-Methoxylphenylthio)-2'-(piperidino)diphenyl sulfide (8h). Oily liquid; ${ }^{1} \mathrm{H}$ NMR $\delta 1.56$ $(\mathrm{m}, 2 \mathrm{H}), 1.71(\mathrm{~m}, 4 \mathrm{H}), 3.01(\mathrm{t}, J=5.1 \mathrm{~Hz}, 4 \mathrm{H}), 3.82(\mathrm{~s}, 3 \mathrm{H}), 6.71(\mathrm{dd}, J=7.9,1.1 \mathrm{~Hz}, 1 \mathrm{H}), 6.81$ $(\mathrm{dd}, J=7.8,1.3 \mathrm{~Hz}, 1 \mathrm{H}), 6.88-6.93(\mathrm{~m}, 3 \mathrm{H}), 7.04-7.20(\mathrm{~m}, 4 \mathrm{H}), 7.37-7.43(\mathrm{~m}, 3 \mathrm{H}) ;{ }^{13} \mathrm{C} \mathrm{NMR} \delta$ 24.8, 26.9, 53.8, 55.8, 115.6, 120.4, 123.6, 124.2, 126.1, 126.7, 127.7, 127.8, 129.2, 130.9, 133.5, 135.9, 137.1, 145.7, 151.7, 161.7; IR (neat) 3040, 2920, 2832, 1579, 1483, 1458, 1435, 1246, $1026 \mathrm{~cm}^{-1}$; MS (EI) m/z $407\left(\mathrm{M}^{+}, 76\right), 350$ (6), 268 (34), 242 (17), 216 (39), 190 (100). Anal. Calcd for $\mathrm{C}_{24} \mathrm{H}_{25} \mathrm{NOS}_{2}$ : C, 70.72; H, 6.18; N, 3.44; S, 15.73. Found: C, 70.58; H, 6.32; N, 3.37; $\mathrm{S}, 15.75$.

$\boldsymbol{N}, \boldsymbol{N}^{\prime}$-Bis[3-\{2-(4-methoxyphenylthio)phenylthio\}phenyl]ethylenediamine (12). Oily liquid; ${ }^{1} \mathrm{H}$ NMR $\delta 3.11$ (m, 4H), 3.85 (s, 6H), 6.78-6.96 (m, 10H), 7.04-7.08 (m, 4H), 7.28-7.41 (m, 4H), 7.41-7.57 (m, 6H), Two NH proton signals are invisible; ${ }^{13} \mathrm{C}$ NMR $\delta 41.0,44.8,54.9,112.4$, $115.3,115.6,120.1,124.0,125.9,128.1,129.1,130.5,132.7,134.3,136.1,136.3,141.4,149.3$, 160.4; IR (neat) 3054, 2968, 2929, 2873, 2352, 1587, 1492, 1442, 1288, 1247, 1172, $1033 \mathrm{~cm}^{-1}$. Anal. Calcd for $\mathrm{C}_{40} \mathrm{H}_{36} \mathrm{~N}_{2} \mathrm{O}_{2} \mathrm{~S}_{4}$ : C, 68.15; H, 5.15; N, 3.97; S, 18.19.

3'-(Diisopropylamino)-2-(4-methoxyphenylthio)diphenyl sulfide (13a). mp 152-154 $\delta$ (nhexane- $\left.\mathrm{CH}_{2} \mathrm{Cl}_{2}\right) ;{ }^{1} \mathrm{H}$ NMR $\delta 3.29(\mathrm{~s}, 8 \mathrm{H}), 3.82(\mathrm{~s}, 6 \mathrm{H}), 6.81-6.94(\mathrm{~m}, 10 \mathrm{H}), 6.97(\mathrm{~s}, 2 \mathrm{H}), 7.01-$ $7.10(\mathrm{~m}, 4 \mathrm{H}), 7.20-7.26(\mathrm{~m}, 4 \mathrm{H}), 7.41(\mathrm{~d}, J=8.7 \mathrm{~Hz}, 4 \mathrm{H}) ;{ }^{13} \mathrm{C} \mathrm{NMR} \delta 49.3,55.8,115.4,115.6$, $118.8,122.7,123.9,126.6,128.2,130.3,132.7,134.3,136.1,136.3,141.6,152.1,160.5$; IR (neat) $3088,3024,1750,1654,1600,1443,1360,1283,1254,1084,877,752 \mathrm{~cm}^{-1}$; FAB MS (EI) $m / z 730\left(\mathrm{M}^{+}\right)$. Anal. Calcd for $\mathrm{C}_{42} \mathrm{H}_{38} \mathrm{~N}_{2} \mathrm{O}_{2} \mathrm{~S}_{4}$ : C, 69.01; H, 5.24; N, 3.83; S, 17.55. Found: C, 68.74; H, 5.45; N, 3.68; S, 17.81 . 
3'-(Dipropylamino)-2-[(4-dipropylamino)phenylthio]diphenyl sulfide (14a). Oily liquid; ${ }^{1} \mathrm{H}$ NMR $\delta 0.85$ (t, $J=7.5 \mathrm{~Hz}, 6 \mathrm{H}), 0.94(\mathrm{t}, J=7.3 \mathrm{~Hz}, 6 \mathrm{H}), 1.59(\mathrm{~m}, 8 \mathrm{H}), 3.15(\mathrm{t}, J=7.8 \mathrm{~Hz}, 4 \mathrm{H})$, 3.25 (t, $J=7.6 \mathrm{~Hz}, 4 \mathrm{H}$ ), 6.48-6.53 (overlap of s and dd, 2H), 6.59-6.64 (overlap of d and d, 3H), $6.81(\mathrm{dd}, J=7.8,1.5 \mathrm{~Hz}, 1 \mathrm{H}), 6.97(\mathrm{td}, J=7.5,1.5 \mathrm{~Hz}, 1 \mathrm{H}), 7.05(\mathrm{td}, J=7.5,1.6 \mathrm{~Hz}, 1 \mathrm{H}), 7.12$ $(\mathrm{t}, J=7.8 \mathrm{~Hz}, 1 \mathrm{H}), 7.25(\mathrm{dd}, J=7.5,1.6 \mathrm{~Hz}, 1 \mathrm{H}), 7.34(\mathrm{~d}, J=8.9 \mathrm{~Hz}, 2 \mathrm{H}) ;{ }^{13} \mathrm{C}$ NMR $\delta 11.39$, 11.42, 20.4 (overlap), 52.8, 52.9, 110.2, 112.4, 113.1, 114.9, 116.9, 125.0, 126.5, 127.8, 129.7, 131.7, 132.9, 135.9, 137.0, 144.1, 148.7, 148.8; IR (neat) 3048, 2944, 2856, 1582, 1493, 1357 , 1094, $1030 \mathrm{~cm}^{-1}$; MS (EI) m/z $492\left(\mathrm{M}^{+}, 98\right), 463$ (83), 232 (18), 217 (100), 184 (40). Anal. Calcd for $\mathrm{C}_{30} \mathrm{H}_{40} \mathrm{~N}_{2} \mathrm{~S}_{2}$ : C, 73.12; H, 8.18; N, 5.68; S, 13.01. Found: C, 73.01; H, 8.29; N, 5.49; S, 13.23. 3'-(Morpholino)-2-(4-morpholinophenylthio)diphenyl sulfide (14b). mp $120-121^{\circ} \mathrm{C}$ ( $n$ hexane- $\left.\mathrm{CH}_{2} \mathrm{Cl}_{2}\right) ;{ }^{1} \mathrm{H}$ NMR $\delta 3.03(\mathrm{~m}, 4 \mathrm{H}), 3.10(\mathrm{~m}, 4 \mathrm{H}), 3.74(\mathrm{~m}, 8 \mathrm{H}), 6.69-6.73(\mathrm{~m}, 2 \mathrm{H}), 6.76-$ $6.84(\mathrm{~m}, 4 \mathrm{H}), 6.90-7.00(\mathrm{~m}, 2 \mathrm{H}), 7.09-7.16(\mathrm{~m}, 2 \mathrm{H}), 7.30(\mathrm{~d}, J=6.9 \mathrm{~Hz}, 2 \mathrm{H}) ;{ }^{13} \mathrm{C} \mathrm{NMR} \delta 49.0$, $49.4,67.1,67.2,114.8,116.5,118.2,121.9,122.6,126.4,128.2,128.4,130.3,132.8,133.7$, 136.3, 142.2, 151.8, 152.3; IR (neat) 3052, 2961, 2852, 1589, 1494, 1446, 1235, $1121 \mathrm{~cm}^{-1}$; MS (EI) $m / z 464\left(\mathrm{M}^{+}, 100\right), 232$ (15), 216 (20), 184 (44). Anal. Calcd for $\mathrm{C}_{26} \mathrm{H}_{28} \mathrm{~N}_{2} \mathrm{O}_{2} \mathrm{~S}_{2}$ : C, 67.21; H, 6.07; N, 6.01; S, 13.80. Found: C, 67.46; H, 6.15; N, 6.01; S, 14.00.

3'-(Piperidino)-2-(4-piperidinophenylthio)diphenyl sulfide (14c). Oily liquid; ${ }^{1} \mathrm{H}$ NMR $\delta$ $1.55-1.72(\mathrm{~m}, 12 \mathrm{H}), 3.12(\mathrm{t}, J=5.4 \mathrm{~Hz}, 4 \mathrm{H}), 3.21(\mathrm{t}, J=5.3 \mathrm{~Hz}, 4 \mathrm{H}), 6.76(\mathrm{~d}, J=7.5 \mathrm{~Hz}, 1 \mathrm{H})$, $6.83(\mathrm{~m}, 2 \mathrm{H}), 6.90(\mathrm{~d}, J=8.8 \mathrm{~Hz}, 2 \mathrm{H}), 6.96-7.02(\mathrm{~m}, 3 \mathrm{H}), 7.14-7.18(\mathrm{~m}, 2 \mathrm{H}), 7.36(\mathrm{~d}, J=8.9 \mathrm{~Hz}$, $2 \mathrm{H}) ;{ }^{13} \mathrm{C}$ NMR $\delta 24.7,26.10,26.14,50.1,50.7,115.7,117.0,119.2,120.3,122.0,126.1,127.9$, $128.1,130.1,132.3,133.9,135.7,136.4,142.3,152.6,153.2$; IR (neat) 3040, 2912, 2840, 2792, 1586, 1491, 1438, 1374, 1230, 1123, $1019 \mathrm{~cm}^{-1}$; MS (EI) $m / z 460\left(\mathrm{M}^{+}, 100\right), 266$ (12), 229 (28), 216 (20), 184 (30). Anal. Calcd for $\mathrm{C}_{28} \mathrm{H}_{32} \mathrm{~N}_{2} \mathrm{~S}_{2}$ : C, 73.00; H, 7.00; N, 6.08; S, 13.92. Found: C, 73.23; H, 7.12; N, 5.93; S, 13.99.

2'-(Morpholino)-2-(4-morpholinophenylthio)diphenyl sulfide (15b). Oily liquid; ${ }^{1} \mathrm{H}$ NMR $\delta$ $3.03(\mathrm{t}, J=4.5 \mathrm{~Hz}, 4 \mathrm{H}), 3.13(\mathrm{t}, J=4.78 \mathrm{~Hz}, 4 \mathrm{H}), 3.78(\mathrm{~m}, 8 \mathrm{H}), 6.68(\mathrm{dd}, J=7.9,1.4 \mathrm{~Hz}, 1 \mathrm{H})$, $6.75(\mathrm{dd}, J=7.8,1.4 \mathrm{~Hz}, 1 \mathrm{H}), 6.83(\mathrm{~d}, J=8.8 \mathrm{~Hz}, 2 \mathrm{H}), 6.89$ (t, $J=7.9 \mathrm{~Hz}, 1 \mathrm{H}), 6.97-7.12(\mathrm{~m}$, $4 \mathrm{H}), 7.27-7.32(\mathrm{~m}, 3 \mathrm{H}) ;{ }^{13} \mathrm{C} \mathrm{NMR} \delta 48.9,52.4,67.2,67.8,116.5,120.4,121.5,125.0,126.0$, 127.0, 127.6, 128.3 129.3, 130.1, 133.3, 135.7, 136.8, 145.9, 150.3, 152.0; IR (neat) 3054, 2959, 2852, 1589, 1497, 1443, 1234, $1117 \mathrm{~cm}^{-1}$; MS (EI) m/z $464\left(\mathrm{M}^{+}, 100\right), 242$ (70), 216 (32), 180 (67). Anal. Calcd for $\mathrm{C}_{26} \mathrm{H}_{28} \mathrm{~N}_{2} \mathrm{O}_{2} \mathrm{~S}_{2}$ : C, 67.21; H, 6.07; N, 6.01; S, 13.80. Found: C, 67.17; H, $6.21 ; \mathrm{N}, 5.87 ; \mathrm{S}, 13.64$.

$\boldsymbol{N}, \boldsymbol{N}$ '-Bis[3-\{2-(4-methoxyphenylthio)phenylthio\}phenyl]piperazine (17). Oily liquid; ${ }^{1} \mathrm{H}$ NMR $\delta 3.29$ (s, 6H), 3.82 (s, 6H), 6.81-6.94 (m, 12H), 6.97 (m, 2H), 7.01-7.10 (m, 4H), 7.20$7.26(\mathrm{~m}, 4 \mathrm{H}), 7.41(\mathrm{~d}, \mathrm{~J}=8.65 \mathrm{~Hz}, 4 \mathrm{H}) ;{ }^{13} \mathrm{C}$ NMR $\delta 49.29,55.76,115.42,115.56,118.82$, $122.70,123.9,126.5,128.1,128.8,130.3,132.7,134.3,136.1,136.3,141.6,152.1,160.5$; IR (neat) 3408, 2928, 1693, 1565, 1472, 1443, 1405, 1325, 1283, 1232, 1184, 1094, 1030, $880 \mathrm{~cm}^{-1}$. Anal. Calcd for $\mathrm{C}_{42} \mathrm{H}_{38} \mathrm{~N}_{2} \mathrm{O}_{2} \mathrm{~S}_{4}: \mathrm{C}, 69.00 ; \mathrm{H}, 5.24 ; \mathrm{N}, 3.83 ; \mathrm{S}, 17.54$. Found: $\mathrm{C}, 69.12 ; \mathrm{H}, 5.21 ; \mathrm{N}$, 3.66; S, 17.71 . 
7,16-Bis[3-\{2-(4-methoxyphenylthio)phenylthio\}phenyl]-1,4,10,13-tetraoxa-7,16-diazacyclooctade-cane (18a). $\mathrm{mp} 141-144{ }^{\circ} \mathrm{C}(\mathrm{EtOH}) ;{ }^{1} \mathrm{H}$ NMR $\delta$ 3.50-3.64 (m, 24H), $3.82(\mathrm{~s}, 6 \mathrm{H}), 6.56$ $(\mathrm{d}, J=8.5 \mathrm{~Hz}, 2 \mathrm{H}), 6.63$ (overlap of $\mathrm{s}$ and d, $4 \mathrm{H}), 6.85-6.88(\mathrm{~m}, 3 \mathrm{H}), 6.91(\mathrm{~d}, J=8.7 \mathrm{~Hz}, 2 \mathrm{H})$, 6.99-7.08 (m, 4H), $7.14(\mathrm{t}, J=7.9 \mathrm{~Hz}, 3 \mathrm{H}), 7.20-7.23(\mathrm{~m}, 2 \mathrm{H}), 7.42(\mathrm{~d}, J=8.9 \mathrm{~Hz}, 4 \mathrm{H}) ;{ }^{13} \mathrm{C}$ NMR $\delta 51.2,55.4,69.0,70.9,110.5,113.7,115.2,118.4,123.5,126.1,127.6,128.2,130.0$, 132.2, 134.2, 135.6, 135.9, 141.1, 148.6, 160.1; IR (neat) 2856, 1579, 1480, 1434, 1246, 1099, $1026 \mathrm{~cm}^{-1}$; FAB MS (EI) $m / z 907\left(\mathrm{M}^{+}, 11\right)$. Anal. Calcd for $\mathrm{C}_{50} \mathrm{H}_{54} \mathrm{~N}_{2} \mathrm{O}_{6} \mathrm{~S}_{4}: \mathrm{C}, 66.19 ; \mathrm{H}, 6.00$; N, 3.09; S, 14.14. Found: C, 66.09; H, 5.97; N, 2.99; S, 14.21.

7,16-Bis[3-\{2-(2,4-dimethoxyphenylthio)phenylthio\}phenyl]-1,4,10,13-tetraoxa-7,16diazacyclo-octadecane (18b). $\mathrm{mp} 64-66{ }^{\circ} \mathrm{C}(\mathrm{EtOH}) ;{ }^{1} \mathrm{H}$ NMR $\delta$ 3.69-3.76 (m, 24H), $3.92(\mathrm{~s}$, $6 \mathrm{H}), 3.96(\mathrm{~s}, 6 \mathrm{H}), 6.61-6.69(\mathrm{~m}, 6 \mathrm{H}), 6.75(\mathrm{~m}, 4 \mathrm{H}), 6.91(\mathrm{~m}, 2 \mathrm{H}), 7.15(\mathrm{~m}, 4 \mathrm{H}), 7.25(\mathrm{t}, J=8.2$, 2H), 7.35 (m, 2H), 7.45 (d, $J=8.3 \mathrm{~Hz}, 2 \mathrm{H}$ ); IR (neat) 3408, 1568, 1437, 1091, 1030, 876, 790, $739 \mathrm{~cm}^{-1}$; FAB MS (EI) $\mathrm{m} / z 967\left(\mathrm{M}^{+}, 12\right)$. Anal. Calcd for $\mathrm{C}_{52} \mathrm{H}_{58} \mathrm{~N}_{2} \mathrm{O}_{8} \mathrm{~S}_{4}: \mathrm{C}, 64.57 ; \mathrm{H}, 6.04 ; \mathrm{N}$, 2.90; S, 13.26. Found: C, 64.48; H, 6.17; N, 3.01; S, 13.39.

m-CPBA - mediated the oxidation of deuterated 10: To a solution of deuterated 10 (103 $\mathrm{mg}, 0.32$ mmol) in $\mathrm{CHCl}_{3}(30 \mathrm{~mL})$ was added excess $m$-CPBA. The mixture was stirred for $1 \mathrm{~h}$ at room temperature, followed by addition of $\mathrm{K}_{2} \mathrm{CO}_{3}(100 \mathrm{mg}, 0.72 \mathrm{mmol})$, which was stirred for an additional $1 \mathrm{~h}$. Saturated aqueous $\mathrm{NaHCO}_{3}(50 \mathrm{~mL})$ was added. The mixture was extracted with $\mathrm{CH}_{2} \mathrm{Cl}_{2}\left(30 \mathrm{~mL}\right.$ x 3). The combined extract was dried over $\mathrm{MgSO}_{4}$. Removal of the solvent in vacuo gave a residue, which was chromatographed on a silica gel $(7 \times 1.5 \mathrm{~cm})$ using a mixture of EtOAc and hexane $(1: 9)$ to give a mixture of $m$-chlorobenzoic acid and unreacted $m$-CPBA. Subsequent elution with the same solvent mixture (1:3) gave 2-(4-methoxyphenylsulfinyl)diphenyl sulfone (11) $(102 \mathrm{mg}, 83 \%): \mathrm{mp} 121-125^{\circ} \mathrm{C}(\mathrm{EtOH}) ;{ }^{1} \mathrm{H} \mathrm{NMR}$ (500 MHz, $\left.\mathrm{CDCl}_{3}\right) \delta 3.85$ (s, 3H, $\left.\mathrm{CH}_{3} \mathrm{O}\right), 6.97$ (d, $J$ $=9.0 \mathrm{~Hz}, 2 \mathrm{x} \mathrm{H} 2), 7.50(\mathrm{~m}, 2 \mathrm{H}, \mathrm{H} 13$ and H15), $7.57(\mathrm{t}, J=6.87,1 \mathrm{H}, \mathrm{H} 14), 7.80(\mathrm{~m}, 2 \mathrm{H}, \mathrm{H} 7$ and H8), 7.95 (m, 3H, H3, H12 or H16), 8.43 (m, 1H, H6 or H9), 8.49 (m, 1H, H6 or H9); ${ }^{13} \mathrm{C}$ NMR (75 $\left.\mathrm{MHz}, \mathrm{CDCl}_{3}\right) \delta$ 55.6, 114.0, 127.9, 128.6, 128.8, 130.8, 132.8, 133.0, 133.1, 133.2, 133.6, 134.0, 139.8, 141.3, 141.6, 163.5 ; IR (KBr) 3392, 3008, 2928, 1594, 1507, 1491, 1379, 1309, 1270, 1245, 1178, 1052, 1018, 909, $880 \mathrm{~cm}^{-1}$; MS (EI) m/z $389\left(\mathrm{M}^{+}, 40\right), 388$ (9), 325 (18), 123 (100). Anal. Calcd for $\mathrm{C}_{19} \mathrm{H}_{15} \mathrm{DO}_{5} \mathrm{~S}_{2} ; \mathrm{C}, 58.60 ; \mathrm{H}, 4.40 ; \mathrm{S}, 16.46$; Found: C, 57.84; H, 4.31; S, 16.33 .

Determination of the extractive ability

The extraction of metal ions from the aqueous solution into $\mathrm{CHCl}_{3}$ layer was performed in capped test tubes. For blank test, biphasic mixture (the volume of water and chloroform was 2 $\mathrm{mL}$ each) was vigorously stirred for $1 \mathrm{~min}$ and then kept at $25 \pm 1{ }^{\circ} \mathrm{C}$ for $12 \mathrm{~h}$. The concentration of picrate in the aqueous phase was determined by absorption spectroscopy at $354 \mathrm{~nm}$. Likewise the concentration of picrate anion remained in the aqueous phase was determined by the same method. The extractive ability was calculated according to equation 1. All experiments were carried out in duplicate or triplicate and the respective results were averaged. The results are summarized in Table 2. 
Crystal data for 14b: $\mathrm{C}_{26} \mathrm{H}_{28} \mathrm{~N}_{2} \mathrm{O}_{2} \mathrm{~S}_{2}, M=464.62$, triclinic, $a=10.043(2), b=11.070(2), c=$ 12.627(2) $\AA$, $\alpha=105.79(2), \beta=110.56(2), \gamma=102.20(2)^{\circ}, U=1189.2(4) \AA^{3}, T=293(2) \mathrm{K}, P-1$, $\mathrm{Z}=2, \mu\left(\mathrm{M}_{\mathrm{o}}-\mathrm{K}_{\alpha}\right)=0.250 \mathrm{~mm}^{-1}, \lambda=0.71073 \AA$, 4180 reflections measured, 4179 unique $\left(R_{\text {int }}=\right.$ $0.0033)$ which were used in all calculations. Final $R$ indices $[I>2 \delta(I)]: R 1=0.0615, \omega R 2=$ 0.1498. (CCDC 213883, See http://www.ccdc.cam.ac.uk/prods/encifer for crystallographic data in CIF or other format.)

Molecular mechanics calculations (MC/SD conformational searching with MacroModel version 5.0 utilizing $\mathrm{MN}^{+}$force field). Selected bond distances and angles are in the supplemental section. The HOMO - LUMO interaction energies were calculated by HyperChem version 6.03 utilizing $\mathrm{CNDO}$ and $\mathrm{ZINDO} /{ }^{15}$

\section{Acknowledgements}

This work was supported by a Korean Research Foundation Grant (DP - 0261).

\section{References}

1. (a) Shine, H. J. In The chemistry of the sulphonium group Stirling, C. J. M. Ed.; John Wiley and Sons: New York, 1981, Chapter 14, pp 523-570. and references therein. (b) Soroka, M.; Shine, H. J. Tetrahedron 1986, 42, 6111. and references therein. (c) Hoque, A. K. M. M.; Lee, W. K.; Shine, H. J.; Zhao, D. C. J. Org. Chem. 1991, 56, 1332. and references therein. (d) Zhao, W.; Shine, H. J. Tetrahedron Lett. 1996, 37, 1749. (e) Chen, T.; Shine, H. J. J. Org. Chem. 1996, 61, 4716. (f) Qian, D.-Q.; Shine, H. J.; Guzman-Jimenez, I. Y.; Thurston, J. H.; Whitmire, K. H. J. Org. Chem. 2002, 67, 4030. (g) Qian, D.-Q; Shine, H. J.; Thurston, J. H.; Whitmire, K. H. J. Phys. Org. Chem. 2003, 16, 142.

2. (a) Silber, J. J.; Shine, H. J. J. Org. Chem. 1971, 36, 2923. (b) Kim, K.; Hull, V. J.; Shine, H. J. J. Org. Chem. 1974, 39, 2534.

3. (a) Kim, K.; Kim, M. N. J. Heteroccycl. Chem. 1997, 34, 1 (b) Kim, K.; Rim, H. J. Tetrahedron Lett. 1990, 31, 5631.

4. Kim, J. Y.; Kim, K. J. Heterocycl. Chem. 1998, 35, 235.

5. Kim, K. S.; Kim, K. Supramol. Chem. 1999, 10, 263.

6. Kim, J. Y.; Kim, K. S.; Kim, K. J. Heterocycl.Chem. 1999, 36, 617.

7. Shin, S. S.; Kim M. N.; Kim, H. O.; Kim, K. Tetrahedron Lett. 1993, 34, 8469.

8. Kim, K. S.; Ha, S. M.; Kim, J. Y.; Kim, K. J. Org. Chem. 1999, 64, 6483.

9. March, J. Advanced Organic Chemistry, John Wiley and Sons: New York; 1992; Chapter 13, pp 641-676.

10. Sevdic, D.; Fekete, L.; Meider, H. J. Inorg. Nuclear Chem. 1980, 42, 885. 
11. For a reference on the ionic radii, see: Sienko, M. J.; Plane, R. A. Chemical Principles and Properties, McGraw-Hill, 1974.

12. Mohamadi, F.; Richards, N. G. J.; Guida, W. C.; Liskamp, R.; Lipton, M.; Caufield, C.; Chang, G.; Hendrickson, T.; Still, W. C. J. Comput. Chem. 1990, 11, 440.

13. (a) Roesky, H. W.; Andruh, M. Coord. Chem. Rev. 2003, 236, 91. (b) Tsuzuki, S.; Honda, K.; Azumi, R. J. Am. Chem. Soc. 2002, 124, 12200.

14. Janiak, C. J. Chem. Soc., Dalton Trans. 2000, 3885.

15.Refer to the reference: Niewa, R.; Zherebtsov, D. A.; Leoni, S. Chem.-A Eur. J. 2003, 9, 4255.

16. (a) Wilhelm, M.; Berssen, E.; Koch, R.; Strasdeit, H. Monatsh. 2002, 133, 1097. (b) Gokel, G. W. Chem. Soc. Rev. 1992, 21, 39.

17. Armarego, W. L. F.; Perrin, D. D. Purification of Laboratory Chemicals, ButterworthHeinemann: Oxford, 1996, pp 51-52. 